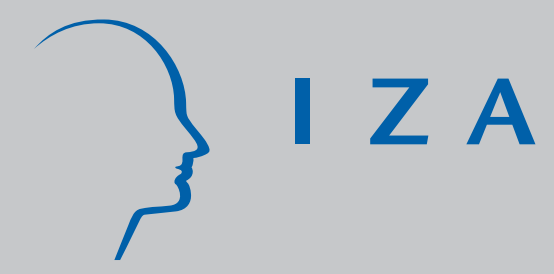

IZADP No. 1973

Ottoman Conquests and European Ecclesiastical Pluralism

Murat lyigun

February 2006 


\title{
Ottoman Conquests and European Ecclesiastical Pluralism
}

\author{
Murat lyigun \\ University of Colorado, Sabanci University \\ and IZA Bonn
}

Discussion Paper No. 1973

February 2006

IZA

\author{
P.O. Box 7240 \\ 53072 Bonn \\ Germany
}

Phone: +49-228-3894-0

Fax: +49-228-3894-180

Email: iza@iza.org

\begin{abstract}
Any opinions expressed here are those of the author(s) and not those of the institute. Research disseminated by IZA may include views on policy, but the institute itself takes no institutional policy positions.

The Institute for the Study of Labor (IZA) in Bonn is a local and virtual international research center and a place of communication between science, politics and business. IZA is an independent nonprofit company supported by Deutsche Post World Net. The center is associated with the University of Bonn and offers a stimulating research environment through its research networks, research support, and visitors and doctoral programs. IZA engages in (i) original and internationally competitive research in all fields of labor economics, (ii) development of policy concepts, and (iii) dissemination of research results and concepts to the interested public.
\end{abstract}

IZA Discussion Papers often represent preliminary work and are circulated to encourage discussion. Citation of such a paper should account for its provisional character. A revised version may be available directly from the author. 
IZA Discussion Paper No. 1973

February 2006

ABSTRACT

\section{Ottoman Conquests and European Ecclesiastical Pluralism}

This paper emphasizes that the evolution of religious institutions in Europe was influenced by the expansionary threat posed by the Ottoman Empire five centuries ago. This threat intensified in the second half of the 15th century and peaked in the first half of the 16th century with the Ottoman Empire's territorial expansion in Eastern Europe. Various historical accounts have suggested that the Ottomans' rise helped the Protestant Reform movement as well as its various offshoots, such as Zwinglianism, Anabaptism and Calvinism, survive their infancy and mature. In an attempt to conceptualize these effects, I develop a model in which social, cultural or religious affiliation between otherwise heterogenous and conflicting groups can lead to cooperation (at the very least, to a secession of hostilities) when such groups are faced with the threat of potentially stronger rivals of a different affiliation. The overall patterns of conflict in continental Europe as well as those between the Protestant Reformers and the Catholic Counter-Reform movement between the 15th and 17th centuries support the idea that Ottoman military conquests in Europe significantly reduced intra-European feuds.

JEL Classification: $\quad$ C72, D74, N33, N43, O10

Keywords: cooperation, conflict, religion, institutions, economic development

Corresponding author:

Murat Iyigun

University of Colorado at Boulder

Department of Economics

Campus Box 256

Boulder, CO 80309-0256

USA

Email: murat.iyigun@colorado.edu

\footnotetext{
* For useful comments, I thank Benito Arrunada, Ann Carlos, Tarhan Feyzioglu, Asli Gocer, Naci Mocan, Shuichiro Nishioka, Sevket Pamuk, David Pinto, Dani Rodrik, Carol Shiue, Stergios Skaperdas and Bridget Strand. I am especially indebted to Zvi Eckstein, Haggay Etkes, Joel Mokyr, and Timur Kuran for their detailed critique and Peter Brecke for making his Conflict Catalog Dataset available to me. All errors and speculations are mine.
} 
"Modern history of Europe begins under stress of the Ottoman conquest."

Lord Acton, (1834-1902).

"Mamma, li Turchi!"

Anonymous, Italy.

\section{Introduction}

Secularism and religious pluralism have arguably become two of the most fundamental features of European socio-political organization since the 17th century. In this paper, I claim that they are both, to some degree, artifacts of the conflict between the Ottoman Empire and the European secular and ecclesiastical powers.

My general argument is that international conflicts, rivalries and cooperation can influence the evolution of socio-political institutions. The fluidity with which civilizations, empires, societies have appeared on and disappeared from the historical stage as a result of foreign animosities is a testament to the fact that domestic power struggles were often rendered irrelevant in their longer term impact on domestic institutions. In what follows, I argue that attempts to understand the evolution of the socio-political institutions in Western Europe and, in particular, how religious pluralism emerged, was tolerated and sustained in Europe requires an emphasis on the conflict between the Ottomans and the Europeans. This conflict intensified with the conquest of Istanbul in 1453 by the Ottoman Empire and reached its zenith in the early 16th century with the Ottoman's capture of Belgrade in 1522, their victory against Hungary in the Mohacs Battle in 1526, and their first siege of Vienna in 1529.

The general idea I advocate below is laid out by Wright (2000). His view is that societies - in particular socio-economic and political institutions - have evolved over time to reflect more complexity and interdependence between heterogeneous cultures and social groups. The main reason for this is that conflict and survival has been a constant in the history of humankind and, when faced with unusual external threats, societies have adapted to learn to cooperate with or at least tolerate the existence of other cultureseven if they might have had a long history of animosity and conflict-to thwart and deflect such threats. 
This paper has two main parts. In the first one, I present a simple conceptual framework that merges Wright's idea with a standard model of appropriative conflict and cooperation. The notion that appropriation and violent conflict over the ownership for resources should be modeled as an alternative to economic production was originally articulated by Haavelmo (1954) and further developed by follow-up papers such as Grossman (1994), Grossman and Kim (1995), Grossman and Iyigun (1995, 1997), Skaperdas (1992, 2005), Alesina and Spolaore (2006) and Hafer (2006). My model differs from these existing models of cooperation and conflict because I embed cultural/religious differences as a source of heterogeneity into a standard model of appropriative conflict and emphasize it as a determinant of conflict and cooperation a la Wright. That is, ceteris paribus, I assume that cultural/religious affinity helps two social groups to cooperate more easily. In particular, I promote the notion that cooperation among heterogeneous groups are easier to sustain when otherwise different groups share some common social code (such as religion, ethnicity or cultural traits). If various social groups are in conflict over the property claims on productive resources and they begin to face an external threat by a potentially stronger rival who subscribes to a different social code, the groups' survival hinges upon at least halting the local hostilities to thwart the external threat. Learning to coexist or cooperate is more easily achieved among different groups when they share a common social, ethnic or religious code. Of course, coexistence or cooperation will not ensure that the external threats are successfully deflected. But, conditional on the survival of the society, it can promote tolerance and the emergence of institutions commensurate with coexistence.

In essence, I apply Wright's reasoning to identify why the European ecclesiastical landscape evolved to produce more religious pluralism during the 15 th and 16th centuries when, not coincidentally, the Ottoman military prowess was at its pinnacle. ${ }^{1}$ The

\footnotetext{
${ }^{1}$ There had been some early precedents of the Protestant movement in France and the Netherlands. For example, the French and Dutch Humanists (of the North) began showing concern for the reform of the Catholic Church starting in the late 15th century, and some Humanists later became associated with the Protestant Reformation. In the late 1550s, the French Humanists began to be called Huguenots (for more details, see Anderson, 1967). Nonetheless, European religious pluralism became official in 1555 with The Religious Peace of Augsburg. It "formally recorded the decision of the Reichstag by which Lutheranism was recognized as an official religion in Germany and legal equality granted to all worshippers of that faith" (see Fischer-Galati, 1959). The Counter-Reformation which began as an internal reform movement within the Catholic Church and yielded the Thirty-years War in the 17th
} 
European history literature contains many accounts of the role of the Ottoman military supremacy holding in check the appetites of the Hapsburg Empire and the Papacy for oppressing the Lutheran movement in its infancy; I shall survey some of these works in greater detail in a separate section below. ${ }^{2}$

Utilizing a comprehensive dataset on violent conflicts for a three-and-a half century interval between 1400 and 1750, I find strong empirical support for the idea that Ottoman military engagements in continental Europe lowered the number and extent of violent conflicts among the European states themselves, while Ottoman military actions in other regions or its domestic civil discords raised them. The Ottoman-threat-cum-Europeancohabitation effects were long lasting and quantitatively very significant: in the 151year span between 1450 and 1600, when there were roughly 1.43 conflicts among the Europeans per annum (or 215 intra-European military engagements in total during that timespan), Ottoman military expeditions in Europe lowered the number of conflicts by about 32 percent while Ottoman military actions in other regions raised them by roughly 40 percent. Furthermore, I find some support for the idea that the Ottomans' influence on the Europeans applied even more narrowly to the feud between the Protestant Reformers and the Catholic establishment: between 1450 and 1700, the likelihood and timing of military engagements between the Protestant Reformers and the Counter-Reformation forces (such as the Schmalkaldic Wars, 1546-47, the Thirty-Years War, 1618-48, and the French Wars of Religion, 1562-98) depended negatively and statistically significantly on Ottomans' military activities in Europe.

In the second part of the paper, I argue that the survival and official recognition of Protestantism-subsequently of Calvinism too-had a profound impact on the European religion market. ${ }^{3}$ That religious pluralism generated competition between different

century to regain the territories lost to Protestantism did not succeed in changing the religious landscape of the continent. In fact, The Peace of Westphalia not only reaffirmed the Peace of Augusburg, but also recognized the Reformed Churches of the Calvinists and Huguenots from around Europe (see Anderson, 1967).

${ }^{2} \mathrm{~A}$ non-exhaustive list of historians who subscribe to this line of argument includes Benz (1949), Fischer-Galati (1959), Setton (1962), Coles (1968), Inalcik (1970), Max Kortepeter (1972), Shaw (1976), Goffman (2002), and MacCulloch (2003).

${ }^{3}$ In fact, the Ottomans' European aspirations and conquests influenced Europe through another important channel: Besides the impact of the Ottomans on religious pluralism in Europe, their expansion and territorial gains in Eastern Europe and the Mediterranean during the 15th century seem to have provided an impetus for the Portuguese and Spanish maritime expeditions in the Atlantic. There is some 
Christian denominations is a direct corollary of the spatial competition model of Hotelling (1929) applied to the religion market and espoused more recently by Barro and McCleary (2005). And while the extent to which religious pluralism and tolerance played a role in European Enlightenment is somewhat contestable, ${ }^{4}$ that European Enlightenment was an important precursor for the Industrial Revolution finds solid historical support. ${ }^{5}$

There are at least three aspects of the idea I espouse that needs clarification and some further elaboration. The first one involves the assumption that cultural/religious affinity helps two social groups to cooperate more easily. As I discuss further in Section 5.1 , there was some variance in the extent to which European secular powers and the various European minorities from different Christian denominations coalesced with the Ottomans. Even as early as the late 15th century, the Catholic Popes Innocent VIII and his successor Alexander VI cooperated with the Ottoman Sultan Bayezit in jailing the latter's younger brother Cem-who had sought the aid of the Knights of Saint John to succeed the Ottoman throne-in exchange for assurances of nonaggression and a subsidy (see Frazee, 1983, pp. 19-22). In the early as the 16th century, the French Emperor Francis was more ready and willing than the Hapsburgs and the Catholic Papacy to cooperate with the Ottomans and lean on this alliance in his geopolitical rivalry with the Hapsburgs and the Italian city-states. In the 17th century, political alliances between Poland-Lithuenia, Sweden and the Ottomans became relevant and England began to trade cannon, gunpowder, lead and woolens with the Empire (Max Kortepeter, 1972, p. ix). In addition, various scholars have documented that the Ottomans' deliberate policies of low taxes and religious toleration generally helped to "divide and conquer" Eastern Orthodox Christian communities in the Ottoman domains from the Catholic

historical evidence to suggest that the Ottomans' presence solidified the financial relationship between the Genoans and the Iberian kingdoms. This association, which materialized in large part due to the loss of the Genoans' dominance of east Mediterranean maritime trade, subsequently played a crucial role in the colonization of South and North America and the development of Atlantic trade.

Also, Portuguese maritime expeditions in the Atlantic were initially driven to some extent by the hope and rumors that there existed a distant Christian Kingdom in the west which had proven to be a stalwart ally against Islam (MacCulloch, 2003, p. 63).

While I do not eloborate on this topic below, in a companion paper, Iyigun (in progress), I focus on such implications of the Ottomans' rise for European trade and economic and political orientation.

${ }^{4}$ For more background on this link, see Rosenberg and Birdzell (1986), Hill (1967), MacCulloch (2003, pp. 674-83).

${ }^{5}$ For details and reference, see Mokyr (2002). 
West, at least until the 18th century. ${ }^{6}$ As Kuran (2004a) argues, the evolution of the political and social institutions in western Europe and the simultaneous stagnation of the Ottoman state jointly helped patch this division between the Christian Ottoman diaspora and the Europeans over time. Without discounting these exceptions, I provide references from the political science literature in Section 2 as well as specific historical references regarding the conflict between the Ottomans and the Europeans in Section 5 which document that cultural and religious affinity played some role in influencing cooperation among the Europeans in their rivalry with the Ottoman Empire.

Second, external threats do not ensure the survival of a particular domestic group even if they encourage cooperation and coexistence among the threatened. Perhaps the most salient verification of this point was provided by Pirenne $(1937,1956)$ who claimed that the rise of Islam in the 7th and 8th centuries-not the Germanic invasion of the earlier centuries-led to the downfall of the Mediterranean world of Antiquity.

Third, it is not clear that serious external threats ought to immediately and always suppress conflicts and permanently generate domestic tolerance, coexistence and the social contracts (explicit or implicit) commensurate with the latter. Rather, my primary emphasis here is that credible external threats could subside internal conflicts to a sufficient degree that, to the extent that domestic struggles continue later on, they are more likely than not to involve parties which had the time to ensure their longer-term survival. Indeed, as I elaborate further in Section 5.2, tolerance and the acceptance of coexistence emerged in Europe only after the Reformation and Counter-Reformation wars which yielded some of the bloodiest episodes of conflict in continental Europe during the 16th and 17th centuries. And, as I shall show below, such conflicts heightened when the Ottoman threat ebbed and subdued when it peaked. That noted, once the Ottoman threat aided the survival of Protestantism in its infancy and it became clear after its official recognition in 1555 that the Counter Reformation Wars would not be able to reclaim the lands lost to Protestantism in central and Northern Europe, religious tolerance became more widely accepted (see, for example, Fischer-Galati, 1959 and MacCulloch, 2003).

Put somewhat differently, I differ from Wright in one important aspect: while external threats unambiguously raise the necessity for domestic coexistence and collusion

\footnotetext{
${ }^{6}$ For reference, see Kafadar (1996), Shaw (1976) and Karpat (1974).
} 
thereby weakening (strengthening) the socio-political and economic power of the incumbents (opposers), their longer term impact on domestic socio-political organization will depend on the position of the incumbents from a Hotelling's spatial competition perspective. My main emphasis here is that, in the 15th and 16th century Europe, the Catholic ecclesiastical order left room for a desire for less involvement in material life and greater accountability, which the survival and spread of the Protestant Reforms helped to instigate and sustain.

Along these lines, it is important to acknowledge that the recognition of Protestantism by the Hapsburgs with the Peace of Augsburg in 1555 does not represent the only or even the first case of deviation from ecclesiastical monopoly. Hence, it is important to distinguish at the outset why denominational plurality in Europe in the 16th century due to the official recognition of Protestantism led to a gradual weakening of the influence of the Catholic Church on material life and why, for example, the Great Chism of 1054 between the East Orthodox Church and the Western Catholics did not produce a similar outcome earlier.

To begin with, the Lutheran movement represented a Catholic reform movement within the geographic domain of the Catholic Church. It arose in reaction to the Church's practice of indulgence sales. In the 14th century it had become acceptable for the Catholic Church to accept financial payments in exchange for making available the "treasury merits" of Holy Christ and those of the saints, headed by Mother Mary, to assist the Christian laity's repentance. This practice intensified in the 15th century eventually drawing the ire of Martin Luther (see MacCulloch, 2003, pp. 118-119). Thus, by construction, Protestantism clearly and unambiguously represented a more secular alternative religious interpretation than the one offered by the Catholic Church at the time. The Calvinist movement that followed solidified further the delineation of the pursuit of spiritual and material advancement because it promoted the idea that seeking material advancement through hard work was an alternative form of service to God (see Rosenberg and Birdzell, 1986, pp. 129-130). Similarly Anabaptism, which emerged as an offshoot of the Zwinglian Reformation in Zurich came to promote a congregational system of polity and an absolute separation of the church and the state (see Anderson, 1967, pp. 50-51). Also, in thinking about why the Eastern Orthodox Church and the 
Great Chism of 1054 did not produce the kind of religious competition attributed to the recognition of Protestantism in 1555, it is important to recognize that the two churches had split geographically with the end of the Roman Empire in 476 A. D. when the last Roman Emperor was deposed and sent to the Eastern Byzantine part of the empire, which survived another millennium until 1453. Thus, even before the Great Schism, it is not clear that the Orthodox and Catholic Churches were competing in the same religion market. Also, while there had been some demands for the reform of the Orthodox Church in the 8th and 9th centuries, the status quo was eventually restored in the Eastern Orthodox Church (MacCulloch, 2003, pp. xviii-xix).

There are three broad strands in the economics, history and political science literatures to which the work below is related. First, following in the footsteps of North (1990), papers such as Acemoglu, Johnson, and Robinson (2001, 2005) and Rodrik, Subramanian, and Trebbi (2004) have argued that legal and contracting institutions have been more important than geography and human capital in influencing economic progress in the long run. Nonetheless, institutions are endogenous and recent efforts to explain how they evolve are divided along two main branches. One, spearheaded by contributions such as Glaeser et al. (2004), mainly articulates that human capital trumps institutions in explaining long-run economic growth and that institutions evolve with changes in human capital attainment. The second effort, advocated by Acemoglu, Johnson and Robinson (2005) and Acemoglu and Robinson (2005), is the idea that domestic political, economic power struggles define institutional characteristics. The work here complements these ideas by emphasizing international conflicts, rivalries and cooperation as potential determinants of the evolution of socio-political institutions.

The second strand to which this paper is related emphasizes religion, social norms and culture as important factors in individual behavior and/or social organization. The main focus of some papers in this strand is religion and culture in general (e.g., Greif, forthcoming, North, 1990, Iannaccone, 1992, Temin, 1997, Glaeser and Sacerdote, 2002, Barro and McCleary, 2005, Guiso, Sapienza and Zingales, 2003, forthcoming, and Spolaore-Wacziarg, 2005), while others in this literature emphasize how individual behavior and the evolution of socio-political institutions are driven by a specific religion, like Judaism, Islam or within different denominations of Christianity (e.g., Botticini and 
Eckstein, 2005, Kuran, 2004b, 2005, and Arrunada, 2005).

Finally, the work here borrows essential ideas from a strand in the political science literature which has emphasized that the rise of the nation state and the consolidation of secular power between the 16th and mid-20th centuries was primarily driven by advances in military technology and the rise in external threats commensurate with these advances (e.g., McNeill, 1984 and Tilly, 1992).

The remainder of this paper is organized as follows: In the next section, I summarize the key ingredients of the conceptual model and discuss the historical or economic justifications for them. In Section 3, I present the conceptual framework that is the basis of the empirical work. In Section 4, I discuss my main empirical findings. In Section 5, I review some historical accounts that relate to my analyses. In Section 6, I conclude.

\section{The Key Ideas}

(a) Cultural/Religious differences are significant in explaining the historical patterns of violent conflict and cooperation. Too many anecdotal examples can be discussed here to justify this claim. Key among those, of course, are the eight Crusades that took place between the 11th century and the 13th century, the Thirty-Years War which took place between 1618 and 1648 and involved all of the West European countries and the Spanish Inquisition, which the reigning King of the Hapsburgs Ferdinand I began in 1478 with the intent of unifying Spain under Catholicism.

Systematic analyses of the causes of conflict and cooperation yield more specific support for this observation. In compiling a dataset with over 300 violent conflicts around the world between 1820 and 1949, Richardson (1960) reveals that differences of religion, especially those of Christianity and Islam, have been causes of wars and that, to a weaker extent, "Christianity incited war between its adherents." In addition, Richardson identifies that war alliances have had an influence in preventing wars between former allies, although this influence declined with the passage of time since the alliance. As Wilkinson (1980) points out, Richardson's analysis applies more broadly in the sense that "the propensity of any two groups to fight increases as the differences between them (in language, religion, race, and cultural style) increase." Taken together, these findings support the notion that social, cultural and religious differences have been important 
causes of violent conflicts and that alliances formed in such conflicts between different social groups have had some lasting effects.

(b) The Ottoman expansion in Eastern Europe, especially between the 1450s and 1570s, was a serious threat to European survival. Take a look at the maps in Figures 1 and 2. Figure 1 shows a map of Europe, North Africa and the Near East at the turn of the 14th century and the one in Figure 2 shows the same geographic region at the turn of the 17 th century.

[Figures 1 and 2 about here.]

There are two striking aspects of the comparison between the two maps. One is the overwhelming territorial gains made by the Ottoman Empire, most of which took place between the mid-15th century and the end of the 16th century. The Ottoman state was formed around Bursa in west-central Anatolia in 1299. By the end of the 16th century, the Ottomans controlled all of the Balkans; had conquered the city of Istanbul (in 1453) thereby ending the East Roman (Byzantine) Empire and giving the Ottomans full control of the Bosphorus and Dardanelles straits (which connect the Black Sea to the Mediterranean); had gained important military victories against Hungary in central Europe (like the capture of Belgrade in 1521 and the Mohacs Battle in 1526); had established a garrison in the Principality of Taranto in the Italian Peninsula (in 1481); and had put Vienna, the capital of the Austrian Monarchy, under what eventually turned out to be the first of two unsuccessful sieges (in 1529). ${ }^{7}$ One can also infer from the comparison of the two maps that a significant degree of political consolidation also accompanied the Ottoman expansion in continental Europe. ${ }^{8}$

The capture of Istanbul by the Ottoman Turks in 1453 was a double blow to Christian Europe because of its strategic importance for Medieval trade and commerce.

\footnotetext{
${ }^{7}$ For references on the history of the Ottoman Empire, see Faroqhi (2004), Kinross (1979), Inalcik (1973), Karpat (1974), and Goodwin (2000).

${ }^{8}$ Although I do not expound on this issue further, this consolidation is indicative of another channel through which the Ottomans potentially affected Europe. According to a relevant hypothesis, military threats necessitate the formation of larger states in order to sustain military establishments commensurate with such threats (i.e., that there are increasing returns to scale in military investments). See, for example, Tilly (1992) and McNeill (1984).
} 
In Figure 3, I replicate a map from Anderson which illustrates the number of sea and overland routes that passed through the city. The map is indicative of the instant and necessary shift of the commercial center of the continent toward the Atlantic seaboard countries after 1453. As Acemoglu, Johnson and Robinson (2005) have recently argued, the creation of the Atlantic trade and its European seaboard played a crucial role in the transmission of the wealth generated by the Atlantic commerce to the rest of the European continent.

[Figure 3 about here.]

The bottomline is that the gains made by the Ottomans in Eastern Europe in the late-15th and early-16th centuries were a threat to the survival of the predominantlyChristian West and Central European states. To be sure, the Ottoman advances were neither the first realized by Muslims on the continent nor among those that penetrated deepest the Western and Central parts of the continent. ${ }^{9}$ However, there can be little doubt that the Ottomans represented the most organized and effective Islamic military power the predominantly-Christian continent had ever faced until that time.

\section{A Simple Conceptual Framework}

Let $z_{i}, i=1,2$, denote the endowment of an economy $i$ and let each country's population level be normalized to one. The output of the economy $y_{i}$ is produced using the endowment input $z_{i}$ net of lump-sum taxes $\tau_{i}$ :

$$
y_{i}=z_{i}-\tau_{i}
$$

Each country has a sovereign who taxes the endowment base to raise revenue and

\footnotetext{
${ }^{9}$ The earliest Islamic conquests in the continent began taking place at the turn of the 8th century. By 711 Spain was under full-scale military invasion by the Abbasids who had earlier raided the Iberian peninsula by crossing the Strait of Gibraltar from North Africa (Fletcher, 2003, p. 15 and Anderson, 1967, p. 14). In the late-8th century and throughout most of the 9th century the threat of Viking raids was a serious fact of life in all the coastal areas of the continent including the Mediterranean, Aegean and the Black Seas (Anderson, 1967, p. 20).
} 
uses it to contest the ownership of the endowments of the other country via military action. ${ }^{10}$ Of course, the sovereign can choose peace over war in which case his country will retain its ownership of the endowments $z_{i}$ provided that his country is not attacked by the other state. ${ }^{11}$

If one country declares war on the other, both countries' net endowments $\hat{z}_{i}=z_{i}-$ $\tau_{i}, i=1,2$, become contestable. There are two interpretations we can adopt as to how the military conflict between the two countries is resolved and the contestable resources are allocated following the war. First, we can assume that country $i$ wins the war with probability $p_{i}$ (and that country $-i$ wins it with probability $1-p_{i} \equiv p_{-i}$ ) and that the victorious country claims all of the contestable endowments $\hat{z}_{1}+\hat{z}_{2}$. Second we can assume that, at the end of the conflict, the share $p_{i}$ of the total contestable endowments $\hat{z}_{1}+\hat{z}_{2}$ will be claimed by country $i$ and the remainder $p_{-i}$ will be left for country $-i$. In what follows, I take the first approach although the model is consistent with either of these interpretations.

The relative strength of the militaries decides the likelihood of winning a war. That is,

$$
p_{i}=\frac{\beta_{i} \tau_{i}}{\beta_{i} \tau_{i}+\beta_{-i} \tau_{-i}},
$$

where $\beta, \beta>0$, represents the potency of a country's military strength. Increases in the strength of country $i$ 's military through higher military spending $\tau_{i}$ raise the likelihood that country $i$ wins the military conflict, and increases in the strength of $-i$ 's military lowers the likelihood that country $i$ can claim victory.

\footnotetext{
${ }^{10}$ While I deliberately make no distinction about what the countries' endowments might be, there are at least two plausible interpretations. First, one can literally think of the endowments as the wealth of the landowners, in which case the lump-sum tax would represent a pecuniary and required payment made by the landowners to the sovereign who would use the funds to bankroll his military. Alternatively, the countries' endowments could be interpreted as efficiency units of available manpower. In that case, the tax imposed could be viewed as the soldiering time mandated by the sovereign.

${ }^{11}$ There is an important and untrivial simplification here. I do not distinguish between defensive and offensive military build ups. As a result, if peace prevails as the equilibrium in this model, neither party allocates resources to military fortifications. And if resources are allocated to military activities, then there is always a military conflict. In a more sophisticated version of the model, one could allow the sovereigns to invest in defensive and offensive fortifications separately as in Grossman and Kim (1995). The main point I emphasize here would remain intact under such an extension.
} 
The sovereigns are interested in expanding their tax base and they take into account equations (1) and (2) to maximize it. Thus, the sovereign in country $i$ solves the following problem:

$$
\max _{\tau_{i}} p_{i}\left(\hat{z}_{i}+\hat{z}_{-i}\right)
$$

where $\hat{z}_{i}=z_{i}-\tau_{i}, \hat{z}_{-i}=z_{-i}-\tau_{-i}, \tau_{-i}$ is given, and

$$
\tau_{i} \leq z_{i}
$$

The solution to the problem specified by (3) and (4) yields the following first-order condition for both sovereigns:

$$
\frac{\beta_{2} \tau_{2}}{\beta_{1} \tau_{1}+\beta_{2} \tau_{2}}\left(z_{1}-\tau_{1}+z_{2}-\tau_{2}\right)=\tau_{1}
$$

and

$$
\frac{\beta_{1} \tau_{1}}{\beta_{1} \tau_{1}+\beta_{2} \tau_{2}}\left(z_{1}-\tau_{1}+z_{2}-\tau_{2}\right)=\tau_{2}
$$

Using these first-order conditions, we can solve for the equilibrium amounts of military spending and the expected outcome of the conflict between the two countries. ${ }^{12}$ That is, letting $\psi_{i}, i=1,2$, denote the expected net resource endowments, we have

$$
\tau_{1}=\frac{\sqrt{\beta_{2}}}{\sqrt{\beta_{1}}+\sqrt{\beta_{2}}}\left(\frac{z_{1}+z_{2}}{2}\right), \quad \tau_{2}=\frac{\sqrt{\beta_{1}}}{\sqrt{\beta_{1}}+\sqrt{\beta_{2}}}\left(\frac{z_{1}+z_{2}}{2}\right),
$$

\footnotetext{
${ }^{12}$ In all that follows, I shall assume that the endowments are high enough to produce interior solutions only.
} 


$$
p_{1}=\frac{\sqrt{\beta_{1}}}{\sqrt{\beta_{1}}+\sqrt{\beta_{2}}}, \quad\left(1-p_{1}\right)=\frac{\sqrt{\beta_{2}}}{\sqrt{\beta_{1}}+\sqrt{\beta_{2}}}
$$

and

$$
\psi_{1}=\frac{\sqrt{\beta_{1}}}{\sqrt{\beta_{1}}+\sqrt{\beta_{2}}}\left(\frac{z_{1}+z_{2}}{2}\right), \quad \psi_{2}=\frac{\sqrt{\beta_{2}}}{\sqrt{\beta_{1}}+\sqrt{\beta_{2}}}\left(\frac{z_{1}+z_{2}}{2}\right) .
$$

Now suppose that another country $(i=3)$ emerges as the neighbor of country 2. Only neighboring countries can engage in warfare although all countries can be in conflict at the same time. If all three countries are engaged in military conflict (i.e. when country 2 fights both countries 1 and 3), then I employ a two-stage solution where the conflict between countries 1 and 2 is resolved first followed by the one between country 3 and the victor of the first engagement. Cultural or religious differences factor into this analysis by making the technology of appropriation (i.e., the $\beta$ 's) higher when there is a military conflict between two countries with differences in culture and/or religion. Country 3 subscribes to a different social code than do countries 1 and 2. For illustrative purposes, assume in what follows that $\beta_{1}=\beta_{2}=1$ when and if countries 1 and 2 engage each other and that $\beta_{3}>\beta_{1}=\beta_{2}>1$ when country 1 or 2 militarily engages country 3. These restrictions reflect the fact that cultural or religious differences make military conflicts more enticing and that country 3 has a more potent military technology than either country 1 or $2 .^{13}$

Let us begin with the problem of the sovereign in country 3 in determining its optimal amount of taxes:

$$
\max _{\tau_{3}} p_{3}\left(z_{3}-\tau_{3}+\hat{Z}\right)
$$

\footnotetext{
${ }^{13}$ Of course, in general, either country 1 or 2 could try to cooperate with country 3 in engaging in appropriative military activities against the odd one out. The assumption of a higher appropriation parameter $\beta$ in cutural or religious conflicts is designed to make this outcome less likely in equilibrium. Nonetheless, there were instances when some European countries, most notably France under Francis' rule, cooperated and formed economic ties with the Ottoman Empire even in the early 16th century. See section 5.1 for more details.
} 
taking as given $\hat{Z}$ and

$$
\tau_{3} \leq z_{3}
$$

In equation (10), $\hat{Z}$ denotes the net endowment that country 3 can capture by engaging either (a) country 2 by itself; (b) country 1 or 2 depending on which one emerges as the victorious side in case there is a first-stage conflict between countries 1 and 2; or (c) a coalition of countries 1 and 2 . As we shall examine below, $\hat{Z}$ will depend not only on country 2's decisions but also on those of country 1 . In particular, depending on whether country 1 will choose to engage country 2 in the first stage, aid its conflict with country 3 , or simply wait for the outcome of the conflict between countries 2 and 3 , the net endowment $\hat{Z}$, will differ.

(i) The non-cooperative equilibria: There are two possible non-cooperative equilibria as summarized by items (a) and (b) above. Under case (b), countries 1 and 2 engage each other militarily before the winner of their conflict confronts country 3's threat. Thus, the solutions given by equations (7) through (9) still apply in the first stage with one minor modification: due to the added assumption that $\beta_{1}=\beta_{2}=1$ when countries 1 and 2 engage in conflict, equations (7), (8) and (9) yield equal taxes, identical probabilities of countries 1 and 2 winning the conflict and equal expected endowments. ${ }^{14}$ The net endowments that will be claimed by the victorious country still equals $\left(z_{1}+z_{2}\right) / 2$. As a result, we can rewrite equation (10) as follows:

$$
\max _{\tau_{3}} p_{3}\left(z_{3}-\tau_{3}+\frac{z_{1}+z_{2}}{2}-\tau_{v}\right)
$$

taking as given $\tau_{v}$ (which denotes the optimal taxes that will be set by the victorious country in the first stage, i.e., country 1 or 2), subject to equation (11) and where, due

\footnotetext{
${ }^{14} \mathrm{By}$ assumption, taxes can be reset before each conflict. Hence, the optimal tax amount in the first period is independent of the potential conflict that might take place in the second stage and the level of optimal taxes that would be chosen in it.
} 
to the assumption that $\beta_{3}>\beta_{1}=\beta_{2}>1$, the contest success function when country 3 confronts either country 1 and 2 is given by

$$
p_{3}=\frac{\beta_{3} \tau_{3}}{\beta_{3} \tau_{3}+\beta_{1} \tau_{v}}=\frac{\beta_{3} \tau_{3}}{\beta_{3} \tau_{3}+\beta_{2} \tau_{v}} .
$$

In the second stage when either country 1 or 2 faces country 3 , it solves the following problem:

$$
\max _{\tau_{v}}\left(1-p_{3}\right)\left(z_{3}-\tau_{3}+\frac{z_{1}+z_{2}}{2}-\tau_{v}\right),
$$

subject to (13), taking as given $\tau_{3}$ and the budget constraint

$$
\tau_{v} \leq \frac{z_{1}+z_{2}}{2}
$$

The problems specified in equations (10) through (15) yield the following two firstorder conditions:

$$
\frac{\beta_{1} \tau_{v}}{\beta_{3} \tau_{3}+\beta_{1} \tau_{v}}\left(z_{3}-\tau_{3}+\frac{z_{1}+z_{2}}{2}-\tau_{v}\right)=\tau_{3}
$$

and

$$
\frac{\beta_{3} \tau_{3}}{\beta_{3} \tau_{3}+\beta_{1} \tau_{v}}\left(z_{3}-\tau_{3}+\frac{z_{1}+z_{2}}{2}-\tau_{v}\right)=\tau_{v}
$$

With (16) and (17) and letting $\hat{\psi}_{i}, i=v, 3$, denote the expected net resource endowments, we establish that $\tau_{3}=\tau_{v} \sqrt{\beta_{1} / \beta_{3}}$ and that 


$$
\begin{gathered}
\tau_{v}=\frac{\sqrt{\beta_{3}}}{\sqrt{\beta_{1}}+\sqrt{\beta_{3}}}\left(\frac{z_{1}+z_{2}+2 z_{3}}{4}\right), \quad \tau_{3}=\frac{\sqrt{\beta_{1}}}{\sqrt{\beta_{1}}+\sqrt{\beta_{3}}}\left(\frac{z_{1}+z_{2}+2 z_{3}}{4}\right), \\
p_{3}=\frac{\sqrt{\beta_{3}}}{\sqrt{\beta_{1}}+\sqrt{\beta_{3}}},
\end{gathered}
$$

and

$$
\hat{\psi}_{v}=\frac{\sqrt{\beta_{1}}}{\sqrt{\beta_{1}}+\sqrt{\beta_{3}}}\left(\frac{z_{1}+z_{2}+2 z_{3}}{8}\right), \quad \hat{\psi}_{3}=\frac{\sqrt{\beta_{3}}}{\sqrt{\beta_{1}}+\sqrt{\beta_{3}}}\left(\frac{z_{1}+z_{2}+2 z_{3}}{4}\right) .
$$

To summarize, when countries 1 and 2 choose not to cooperate with each other and the appropriative conflict between the two of them still exists, it yields outcomes that are given by equations (7) through (9). Given the simplification I subscribed to in this subsection, according to which $\beta_{1}=\beta_{2}$, the net aggregate endowments $\left(z_{1}+z_{2}\right) / 2$ will be appropriated with equal likelihood by either country 1 or 2 . Due to the fact that they are the joint target of a military action by country 3 subsequently, the winner of the first stage conflict allocates a positive amount of tax revenue to the conflict with country 3 (which equals $\tau_{v}$ ) and appropriates the aggregate endowments available for grabs in the conflict with country 3 (which equals $\left(z_{1}+z_{2}+2 z_{3}\right) / 4$ ) with a likelihood of $\sqrt{\beta_{1}} /\left(\sqrt{\beta_{1}}+\sqrt{\beta_{3}}\right)$.

The other non-cooperative scenario involves case (a) under which country 1 does not engage in conflict with country 2 in the first stage and awaits the winner of the conflict between countries 2 and 3. In this case, the first-stage outcome will be analogous to those summarized by equation (7) through (9) with the exception that the country subscript 1 ought to be replaced by the subscript 3 in all three equations.

In the second stage, country 1 will face the winner of the conflict between countries 2 and 3 . It will thus solve the following maximization problem:

$$
\max _{\tau_{1}} p_{1}^{v}\left(z_{1}-\tau_{1}+\frac{z_{2}+z_{3}}{2}-\tau_{v}\right)
$$


taking as given $\tau_{v}$, subject to equation (4) and where

$$
p_{1}^{v}=\left\{\begin{array}{ll}
\frac{\beta_{1} \tau_{1}}{\beta_{1} \tau_{1}+\beta_{2} \tau_{2}} & \text { if } v=2 \\
\frac{\beta_{1} \tau_{1}}{\beta_{1} \tau_{1}+\beta_{3} \tau_{3}} & \text { if } v=3
\end{array} .\right.
$$

If country $i, i=2,3$, emerges victorious to face country 1 in the second stage, it will solve the problem

$$
\max _{\tau_{v}}\left(1-p_{1}^{v}\right)\left(z_{1}-\tau_{1}+\frac{z_{2}+z_{3}}{2}-\tau_{v}\right)
$$

subject to (22), taking as given $\tau_{1}$ and

$$
\tau_{v} \leq \frac{z_{2}+z_{3}}{2}
$$

This problem yields two first-order conditions that are similar to those in (16) and (17) and produce the following equilibrium outcomes:

$$
\begin{gathered}
\tau_{v}=\frac{\sqrt{\beta_{1}}}{\sqrt{\beta_{1}}+\sqrt{\beta_{v}}}\left(\frac{z_{2}+z_{3}+2 z_{1}}{4}\right), \quad \tau_{1}=\frac{\sqrt{\beta_{v}}}{\sqrt{\beta_{1}}+\sqrt{\beta_{v}}}\left(\frac{z_{2}+z_{3}+2 z_{1}}{4}\right), \\
p_{1}^{v}=\frac{\sqrt{\beta_{1}}}{\sqrt{\beta_{1}}+\sqrt{\beta_{v}}},
\end{gathered}
$$

and 


$$
\hat{\psi}_{v}=\frac{\sqrt{\beta_{v}}}{\sqrt{\beta_{1}}+\sqrt{\beta_{v}}}\left(\frac{\sqrt{\beta_{v}}}{\sqrt{\beta_{2}}+\sqrt{\beta_{3}}}\right)\left(\frac{z_{2}+z_{3}+2 z_{1}}{4}\right)
$$

and

$$
\hat{\psi}_{1}=\frac{\sqrt{\beta_{1}}}{\sqrt{\beta_{1}}+\sqrt{\beta_{v}}}\left(\frac{z_{2}+z_{3}+2 z_{1}}{4}\right) .
$$

Note that country 1's expected utility prior to the determination of its rival in the second stage is given by

$E\left(\hat{\psi}_{1}\right)=p_{2}^{3}\left[\frac{\sqrt{\beta_{1}}}{\sqrt{\beta_{1}}+\sqrt{\beta_{2}}}\left(\frac{z_{2}+z_{3}+2 z_{1}}{4}\right)\right]+\left(1-p_{2}^{3}\right)\left[\frac{\sqrt{\beta_{1}}}{\sqrt{\beta_{1}}+\sqrt{\beta_{3}}}\left(\frac{z_{2}+z_{3}+2 z_{1}}{4}\right)\right]$,

where $p_{2}^{3}, p_{2}^{3} \equiv\left(\beta_{2} \tau_{2}\right) /\left(\beta_{2} \tau_{2}+\beta_{3} \tau_{3}\right)$, denotes the probability that country 2 beats country 3 in their first-stage military conflict.

By comparing equation (20) with (27) and (28) we can establish that it is optimal for neither country 1 nor 2 to engage each other in a military conflict especially if $z_{1} \geqslant$ $z_{3}$.

(ii) The cooperative equilibrium: The other option is for countries 1 and 2 to cooperate against country 3 . In that case, they will simply agree to stop the military hostilities between them to save resources and allocate them to their joint struggle against country 3. Once the conflict is resolved, they agree to split the war booty peacefully according to a sharing rule that allocates the fraction of net endowments between the two of them. For illustrative purposes, let us assume that they use equation (2) to allocate the appropriated resources, which given the simplifying assumption we have made (i.e., $\beta_{1}$ $=\beta_{2}$ ) splits the spoils of war equally between the two countries for identical levels of taxes, $\tau_{1}=\tau_{2}$. In this case, countries 1 and 2 jointly solve 


$$
\left.\max _{\tau_{1}, \tau_{2}}\left(1-p_{3}^{1,2}\right)\left[z_{3}-\tau_{3}+z_{1}+z_{2}-\left(\tau_{1}+\tau_{2}\right)\right]\right],
$$

where

$$
p_{3}^{1,2}=\frac{\beta_{3} \tau_{3}}{\beta_{3} \tau_{3}+\beta_{1}\left(\tau_{1}+\tau_{2}\right)},
$$

taking as given $\tau_{3}$ and

$$
\tau_{i} \leq z_{i} \quad i=1,2
$$

The problem of country 3 then is

$$
\max _{\tau_{3}} p_{3}^{1,2}\left[z_{3}-\tau_{3}+z_{1}+z_{2}-\left(\tau_{1}+\tau_{2}\right)\right]
$$

taking as given $\tau_{1}, \tau_{2}$ and subject to equations (11) and (30).

The two first-order conditions to these problems are given by

$$
\frac{\beta_{3} \tau_{3}}{\beta_{3} \tau_{3}+\beta_{1}\left(\tau_{1}+\tau_{2}\right)}\left[z_{1}+z_{2}+z_{3}-\left(\tau_{1}+\tau_{2}+\tau_{3}\right)\right]=\left(\tau_{1}+\tau_{2}\right)
$$

and

$$
\frac{\beta_{1}\left(\hat{\tau}_{1}+\hat{\tau}_{2}\right)}{\beta_{3} \tau_{3}+\beta_{1}\left(\tau_{1}+\tau_{2}\right)}\left[z_{1}+z_{2}+z_{3}-\left(\tau_{1}+\tau_{2}+\tau_{3}\right)\right]=\tau_{3} .
$$

On the basis of equations (33) and (34), we have 


$$
\begin{gathered}
\tau_{1}+\tau_{2}=\frac{\sqrt{\beta_{3}}}{\sqrt{\beta_{1}}+\sqrt{\beta_{3}}}\left(\frac{z_{1}+z_{2}+z_{3}}{2}\right), \quad \hat{\tau}_{3}=\frac{\sqrt{\beta_{1}}}{\sqrt{\beta_{1}}+\sqrt{\beta_{3}}}\left(\frac{z_{1}+z_{2}+z_{3}}{2}\right) \\
p_{3}^{1,2}=\frac{\sqrt{\beta_{3}}}{\sqrt{\beta_{1}}+\sqrt{\beta_{3}}}
\end{gathered}
$$

and

$$
\hat{\psi}_{1}=\hat{\psi}_{2}=\frac{\sqrt{\beta_{1}}}{\sqrt{\beta_{1}}+\sqrt{\beta_{3}}}\left(\frac{z_{1}+z_{2}+z_{3}}{4}\right), \quad \hat{\psi}_{3}=\frac{\sqrt{\beta_{3}}}{\sqrt{\beta_{1}}+\sqrt{\beta_{3}}}\left(\frac{z_{1}+z_{2}+z_{3}}{2}\right)
$$

A comparison of equations (20), (28) and (37) reveals that, depending on the relative endowments of the three parties involved, the threat of country 3 can lead to a secession of hostilities between countries 1 and 2. In particular, we find that (28) exceeds (20) for country 1 for all parameter values and that (27) exceeds (20) for country 2 as long as $z_{1} \geqslant z_{3}$. As a consequence, neither country will have an incentive to attack each other when country 2 is engaged in a conflict with country 3 . In addition, (37) exceeds (27) for all parameter values but it may or may not exceed (28) depending on parameter restrictions. For example, if $\beta_{1} \neq \beta_{2}$, it would be more likely that (37) exceeds (28) for relatively small values of $\beta_{1}$ and larger values of $\beta_{2}$. Thus, we can confirm that cooperation can be the equilibrium outcome for some parameter restrictions where $\beta_{1}<$ $\beta_{2}<\beta_{3}$ and $z_{3} \leq z_{1}$.

Of course, when there are no external threats involved, the cooperative solution cannot be sustained as the equilibria due to the standard Prisoner's Dilemma. However, to the extent that the sovereigns in country 1 and 2 can retain in defeat some control over the allocation of their resources earmarked for their military conflict with country 3 , the cooperative equilibrium can be sustained as time consistent outcome. The reason for this is very simple: if countries 1 and 2 commit to cooperate so that country $i$ chooses $\tau_{i}$ $=0$, country $-i$ will have an incentive to cheat by devoting $\tau_{-i}=\varepsilon, \varepsilon>0$, to appropriate all of country $i$ 's net endowment $z_{i}-\tau_{i}$ before turning to face country 3. Since such 
cheating will leave country $i$ without any resources (except the control of those originally earmarked by it for the military confrontation with country 3 ), it can penalize country $-i$ by making the resources $\tau_{i}$ available to country 3 in its conflict with country $-i$. As a consequence, the expected endowments claimed via the conflict for country $i$ and country 3 will be given by

$$
p_{-i}^{i, 3}=\frac{\sqrt{\beta_{-i}}}{\sqrt{\beta_{-i}}+\sqrt{\beta_{i}}+\sqrt{\beta_{3}}} \quad \text { and } \quad\left(1-p_{-i}^{i, 3}\right)=\frac{\sqrt{\beta_{i}}+\sqrt{\beta_{3}}}{\sqrt{\beta_{-i}}+\sqrt{\beta_{i}}+\sqrt{\beta_{3}}}
$$

and

$$
\begin{gathered}
\hat{\psi}_{-i}=\frac{\sqrt{\beta_{-i}}}{\sqrt{\beta_{-i}}+\sqrt{\beta_{i}}+\sqrt{\beta_{3}}}\left(\frac{z_{1}+z_{2}+z_{3}}{4}\right) \\
\text { and } \\
\hat{\psi}_{3}=\frac{\sqrt{\beta_{i}}+\sqrt{\beta_{3}}}{\sqrt{\beta_{-i}}+\sqrt{\beta_{i}}+\sqrt{\beta_{3}}}\left(\frac{z_{1}+z_{2}+z_{3}}{2}\right) .
\end{gathered}
$$

Note that the payoff to country $-i$, which reneges on its commitment to country $i$, is not higher than its payoff when it abides by its commitment, which is given in equation (37). This is the reason why cooperation between countries 1 and 2 could be sustained when both are faced with an outside threat by country $3 .^{15}$

The crucial element of sustaining cooperation-as opposed to maintaining a trucebetween countries 1 and 2 against the threat of country 3 is the ability to retain full control over the resources marked by each of the first two countries for the military confrontation with country 3. As we shall see in Section 5 below, the extensive negotiations

\footnotetext{
${ }^{15}$ Hence, unlike the cases in which the Political Coase Theorem does not hold because social and political groups bargain in isolation (see, for example, Acemoglu, 2004), it can hold in this model if (i) the players involved are faced with an external threat that can leave both of them worse off; (ii) the bargaining sides commit to a course of action before the outside player makes his move and the bargaining agents respond; and (iii) the bargaining sides can penalize each other by cooperating with the outside player if one of them reneges on his committment.
} 
that took place between the Protestant Reformers and the House of the Hapsburgs, the Holy Roman Empire and the Papacy revolved to a significant extent around this issue.

\section{The Empirical Analysis}

\subsection{Conflict, Truce and Peace in Europe (circa 1400 A.D. -1750 A. D.)}

The conceptual framework presented above implies that the intensity and magnitude of conflict among the Christian populations of Europe in the late-middle ages and the Reformation period ought to have been related negatively to the threat of offensive military action by the Ottoman Empire on the continent. As a corollary, they should have also been related positively to the degree to which the Ottomans were distracted by other endeavours, such as carrying out military offensives against other non-European foes or trying to subdue their own civil discords.

In this subsection, I test this hypothesis using a European conflict dataset covering the period 1400 A. D. to 1750 A. D. The primary source of my empirical work is the Conflict Catalog being constructed by Brecke (1999). It is a comprehensive dataset on violent conflicts in all regions of the world between $1400 \mathrm{~A}$. D. and the present. It contains a listing of all recorded violent conflicts with a Richardson's magnitude 1.5 or higher criterion (32 or more deaths; $\log (32)=1.5$ ) that occurred during the relevant time span in five continents (Europe, Asia, the Americas, Australia, and Africa). ${ }^{16}$ While the Catalog is still under construction, it is virtually complete for Europe and the Near East. It is this portion of the catalog that I rely on below. For each conflict recorded in the catalog, the primary information covers (i) the number and identities of the parties involved in the conflict; (ii) the common name for the confrontation (if it exists); and (iii) where and when it took place. On the basis of this primary data, there also exists derivative information on the duration of the conflict as well as information about the number of fatalities (which is available for less than a third of the total number of observations). I expand this dataset by adding the regional population estimates for Europe and the Ottoman Empire calculated by MacEvedy and Jones (1978), other control variables such

\footnotetext{
${ }^{16}$ Brecke borrows his definition for violent conflict from Cioffi-Revilla (1996): "A war (a 'war event') is an occurrence of purposive and lethal violence among two or more social groups pursuing conflicting political goals that results in fatalities, with at least one belligerent group organized under the command of authoritative leadership."
} 
as time and century dummies, and the average distance of the European and Ottoman conflicts from the Ottoman capital, Istanbul.

I obtain the impact of Ottoman military activities on regional conflicts in continental Europe by estimating the following equation with two alternative sets of time-series data:

$$
\text { EUROPE } E_{t}=\beta_{0}+\beta_{1} O T T O M A N_{t}+\beta_{2} O T H E R O T T O M A N_{t}+\beta_{3} X_{t}+\varepsilon_{t},
$$

where EUROPE $E_{t}$ is the number of violent conflicts that took place over a specified interval of time in continental Europe-either among continental European countries or, as a result of civil conflicts, within them; OTTOMAN is the number of conflicts in continental Europe the Ottoman Empire was engaged in over the relevant time span; and OTHEROTTOMAN is the number of conflicts the Empire was engaged in over the same period in different geographic locations (such as Northern Africa, the Caucuses, the Middle East) as well as the number of violent civil disturbances within its territories. According to the hypothesis I laid out above, $\beta_{1}$ should be negative and $\beta_{2}$ ought to be positive.

In all specifications below, the control variable $X_{t}$ includes a time dummy, TIME, the lagged dependent variable, $E U R O P E_{t-1}$, an estimate of the continental European

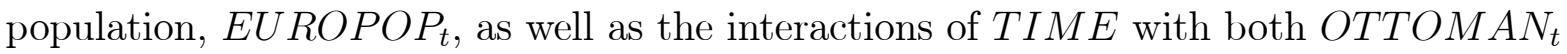
and OTHEROTTOMAN .

The time trend, TIME, is included because political scientists have established that there has been a secular decline in warfare in Europe since the 15th century (see, for instance, Woods and Baltzly, 1915, who first documented this finding; Richarsdon, 1960, who referenced such a trend; Wilkinson, 1980, who could not corroborate it on the basis of the Richardson data; and Brecke, 1999, who did verify this trend utilizing the Conflict Catalog). Furthermore, one could argue, as some historians have done, that the influence of the Ottoman Empire in Europe was at its pinnacle from the capture of Istanbul in 1453 to the Lepanto sea battle in 1571, in which the Holly Empire fleet decimated the entire Ottoman navy and scored the first major victory for the Christian West 
against the Ottomans. ${ }^{17}$ To many historians, this sea battle marked not only a significant setback for the Ottoman naval prowess in the eastern Mediterranean Sea, which the Ottomans never dominated again, but also a psychological momentum shift. This is another reason for which I include a time dummy, TIME, in the empirical analyses below. I include the interaction between the main explanatory variables, OTTOMAN and OTHEROTTOMAN, and the time dummy, TIME, to capture the idea that the impact of Ottoman military activities in Europe and other geographic regions on the patterns of conflict and cooperation in Europe drifted over time. Finally, I include the continental European population level, EUROPOP, in all the regressions as a proxy for per-capita income. ${ }^{18}$

Depending on the parsimony of the empirical specification I employ, other control variables in $X_{t}$ include the following variables: The average duration of continental European conflicts that began in any given period $t, L E N G T H_{t}$; the average length of Ottoman military engagements in Europe that began in $t, O T T O L E N G T H_{t}$; the duration of Ottoman military activities elsewhere that began in $t$, OTHERLENGTH $H_{t}$; the population of Ottoman territories, OTTOMANPOP ; a century dummy, CENTURY; as well as lagged values of the main explanatory variables OTTOM AN and OT HEROTTO$M A N$.

Using the European subset of the Conflict Catalog data, I generate two different datasets to estimate equation (40). My primary data are annual and cover the period between 1450 A. D. and 1600 A. D. which according to most historical accounts corresponds to the interval during which the Ottoman threat to Europe was most intense. This dataset contains 150 annual observations. ${ }^{19}$ My alternative data cover a longer time period between 1400 A. D. and 1750 A. D. and they consist of the number of regional conflicts and the values of other explanatory variables over 5-year intervals. Hence this second dataset contains 70 observations.

\footnotetext{
${ }^{17}$ See, for example, Coles (1968), Goffman (2002), Goodwin (2000), and Kinross (1979).

${ }^{18}$ The time period over which I carry out my empirical analysis covers the Malthusian era when there existed a strong link between the level of per-capita income and population.

${ }^{19}$ To confirm the validity of this empirical specification using annual conflict data, I employed the Dickey-Fuller test for cointegration. At a significance level of one percent, I rejected the existence of a unit root in the number of European conflicts, $E U R O P E_{t}$, and the number of Ottomans' conflicts in Europe and elsewhere, OTTOMAN $N_{t}$ and OTHEROTTOMAN .
} 
Table 1 presents summary statistics of the key variables in the empirical analysis. As can be seen in the top panel, there was on average one Ottoman military action in Continental Europe roughly every three years and about one Ottoman engagement domestically or in other regions every five years between 1450 A. D. and 1600 A. D. This compares with roughly three violent conflicts every two years among continental European countries themselves. The highest number of intra-European conflicts recorded in any given year was 6 in 1519; that between the Ottoman Empire and Europe was 3 in 1551; and the highest number of domestic conflicts in the Ottoman Empire or military excursions in other regions was 3 in 1526. Both the European and the Ottoman population levels are negatively correlated with violent conflicts in Europe (either between the Ottomans and the Europeans or between European countries). This may be reflective of the decreasing propensity for violent conflict over time which, as I have noted above, some political scientists have identified. Note also that there exists a negative correlation between the number of intra-European conflicts and the average length of the Ottoman military excursions in the continent. In contrast, there is a positive correlation between the number of Ottoman military excursions in continental Europe and the average length of intra-European violent conflicts. The lower panel of the same table shows that the summary statistics for the five-year average data is roughly in line with those that are annual.

[Table 1 about here.]

Table 2 shows how the Ottoman military activities between 1450 A. D. and 1600 A. D. influenced those among and within the continental European powers using the annual conflict data. In Tables 2 and 3, columns (1)-(3) show estimates with ordinary least squares (OLS), columns (4) through (6) present those derived with OLS robust errors, and columns (7)-(9) tabulate the results from robust regressions that correct for outlier biases using Cook's D-test.

In columns (1), (4) and (7), I present the estimates from the most parsimonious specification where the number of conflicts among the continental European countries at time $t, E U R O P E_{t}$, is regressed on a time trend, TIME; the European population level 
in year $t, E U R O P O P$; the lagged value of the dependent variable, $E U R O P E_{t-1}$; the number of Ottoman military incursion in Europe during the same year, OTTOMAN the number of conflicts Ottomans were engaged in other regions and their domestic civil unrests, OTHEROTTOMAN ; as well as the interaction of the latter two with the time dummy, TIME *OTTOMAN and TIME*OTHEROTTOMAN . In all estimations, Ottoman military excursions in continental Europe, OTTOMAN, had a statistically significant and negative impact on the number of violent feuds among the Europeans themselves. Moreover, as indicated by the statistically significant and positive coefficient on the interaction term in the robust errors regression in column (4), TIME * OTTOMAN, the conflict-discouraging impact of the Ottoman military engagements in Europe was declining over time (although the impact of this effect was quantitatively small). The effects of Ottoman military engagements in subduing intra-European conflicts were fairly large. On average, one additional Ottoman military engagement in Europe lowered the number of intra-European conflicts by roughly .50. Given that the average number of intra-European violent confrontations was about 1.43 per year, this implies that Ottoman military activities in continental Europe reduced intra-European violent engagements in the same period by more than thirty percent. The only other significant variable in these most parsimonious specifications is the lagged-value of continental European conflicts. Ceteris paribus, a high number of conflicts in any given year reduced violent confrontations in the next year by about 15 percent. Given that the average length of intra-European conflicts was 2.8 years with a high variability of 3.7 years, this is reflective of the fact that most intra-European military confrontations ended within a year.

In columns (2), (5) and (8), I add the average length of intra-European conflicts, $L E N G T H_{t}$, that of Ottoman military actions in continental Europe, OTTOLENGT $H_{t}$, and the duration of Ottoman domestic disturbances and their excursions elsewhere, OTHERLENGTH $H_{t}$, as additional control variables. According to these estimates, the impact of OTTOMAN on intra-European feuds is still negative and significant but even stronger. In addition, given the positive and statistically significant interaction between OTTOMAN and TIME, the discouraging impact of the Ottomans on the Europeans' propensity to fight each other declined over time (although, as before, this 
effect is quantitatively pretty small). The lagged-value of intra-European conflicts still enters negatively and significantly. While the duration of Ottomans' military actions had no significant impact on the number of intra-European conflicts, the average length of European feuds was associated positively and significantly with the average number of European conflicts.

Finally in columns (3), (6) and (9), I add the following control variables: The lagged-value of Ottoman conflicts in Europe, OTTOMAN $N_{t-1}$, the one-period lagged annual number of its domestic disturbances or its military excursions elsewhere, OT HEROT$T O M A N_{t-1}$, a century dummy, CENTURY, the level of population in the Ottoman territories, OTTOMANPOP , and the average distance of intra-European violent conflicts from the Ottoman capital (Istanbul), DISTANCE ${ }_{t}{ }^{20}$ With all these control variables in place, OTTOMAN is still negative and significant at the 5 percent level in the robust errors specification in column (6) and the robust regression in column (9). Moreover, as shown in the OLS estimates in column (3) and the robust errors column (6), the lagged value of Ottomans' domestic disturbances and their military engagements in other geographic regions, OTHEROTTOMAN $N_{t-1}$, comes in with the expected positive and statistically significant coefficient. The magnitude of this coefficient is slightly higher than that on OTTOMAN , suggesting that Ottomans' engagements at home or elsewhere raised the Europeans' propensity to engage each other violently with a one period lag and by about 30 percent.

[Table 2 about here.]

In sum, the empirical results in Table 2 support the notion that intra-European conflicts subsided to a significant degree when the Ottoman Empire went on its military conquests in the continent. Over time, this effect might have subsided to some extent, although the main results are not sensitive to the inclusion or exclusion of various control variables. Furthermore, there is some evidence to imply that intra-European military feuds intensified by a roughly similar magnitude when the Ottomans were distracted by

\footnotetext{
${ }^{20}$ Since OTTOMANPOP, DISTANCE and CENTURY did not enter significantly in either of the three estimates in columns (3), (6) and (9), I have not shown them in Table 2.
} 
military actions in remote geographic regions or by their own civil discords.

Reverse causality generally plagues these kinds of empirical estimates. Given the results above, however, one would have to come up with a plausible reason why the Ottomans would have found it more optimal to engage in European conquests when European societies were not consumed by feuds among themselves. Put differently, the more credible reverse causality argument in this case is that the Ottomans would have preferred to time their European conquests to coincide with more intra-European conflicts, distractions and disagreements not less. As a result, if there is any reverse causality running from the number and timing of violent European feuds to those of Ottoman military actions in Europe, it is plausible that it generates attenuation bias. Nonetheless, to address the reverse causality concern as best as possible given the data limitations, I ran the regressions reported in columns (1) through (9) using the lagged values of the two key right hand side variables, OTTOMAN $N_{t-1}$ and OTHEROTTOMAN $N_{t-1}$ and other control variables only. The results, which are shown in Table 3, reveal that the impact of the lagged-value of Ottoman military conflicts on intra-European feuds is even more significant and stronger. As can be seen, the lagged number of conflicts the Ottomans were engaged in continental Europe, OTTOMAN $N_{t-1}$, comes in with a negative and statistically significant sign in all nine estimates. In addition, the estimated coefficient on OTTOMAN $N_{t-1}$ generally is in the range of -.53 to -.67 which implies a larger impact on intra-European conflicts than those in Table 2. The estimates of the impact of Ottoman engagements elsewhere and at home, OT HEROTTOM $A N_{t-1}$, comes in with the expected positive sign although it is significant at the 5 percent confidence level only in the specification in column (4). ${ }^{21}$

[Table 3 about here.]

Further caution is needed in interpreting these results. Given that the data cover a three-and-a-half century time span more than six hundred years ago and try to fully account for the timing and magnitude of all violent conflicts over that period which

\footnotetext{
${ }^{21}$ Again, due to the fact that OTTOM ANPOP and CENTURY did not enter significantly in either of the three estimates in columns (3), (6) and (9), I do not report them in Table 3.
} 
yielded at least 35 deaths, they are likely to be very noisy and patchy over some shorter time intervals. This would obviously generate some attenuation bias.

In the empirical estimates presented in columns (3), (6), and (9), I included some controls for the distance of conflicts from the Ottoman capitol Istanbul. The justification for this is that the actions of the Ottomans should have had a larger (smaller) impact on intra-European feuds that were closer (distant) to the Ottoman frontier. In none of those specifications, the distance variable I constructed, namely the average distance of intra-

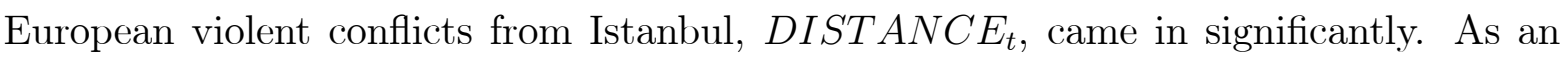
alternative dependent variable, I constructed the ratio of the number of intra-European conflicts in any given year, $E U R O P E_{t}$, to the average distance of these conflicts to the Ottoman capital, DISTANCE , and regressed it on the explanatory variables utilized in Table $2 .^{22}$ The results are shown in the first three columns of Table 4 . They verify that the distance adjusted number of intra-European conflicts depended negatively and significantly on the number of Ottoman military actions in Europe, although this conclusion is not robust to the removal or down-weighing of some outliers as shown in column $(3){ }^{23}$

As another alternative test of the idea that Ottoman military involvements in Europe had a stronger discouraging effect on intra-European violent feuds that were closer geographically, I first eliminated all the years in which there were no intra-European violent feuds (36 observations) and treated DISTANCE $E_{t}$ as the dependent variable. The results are shown in columns (4), (5) and (6) of Table 4. According to the results, when Europeans were engaged in violent feuds among themselves, it was more likely that their confrontations took place in parts of Europe that were farther away from the Ottoman frontier when the Ottomans were militarily active in continental Europe. In particular, an additional Ottoman military engagement in Europe in any given year, OTTOMAN , raised the average distance of intra-European violent conflicts from Istanbul by about 110 miles. While this effect is significant only in the robust regression specification, it comes in with the expected positive sign in the other two regressions and attains a

\footnotetext{
${ }^{22}$ Specifically, I contructed this variable as the ratio of $E U R O P E_{t}$ to DISTANCE plus 0.1 to keep it defined at zero when there were no violent intra-European conflicts in a period $t$.

${ }^{23}$ The complete specifications included the additional distance variables as well as their interactions with time. However, since neither of these variables entered significantly in the estimates in columns (1), (2) and (3), I do not show them.
} 
p-value of 14 and 17 percent respectively in columns (4) and (6).

Yet another issue is that the length of the conflicts varied. To the extent that some but not all battles and conflicts dragged on longer than a year, the empirical results could be biased. In the empirical specifications in columns (4) through (9) in Tables 2 and 3, I attempted to control for this by including the average duration of continental European conflicts that began in any given period $t, L E N G T H_{t}$, the average length of Ottoman military engagements in Europe that began in $t, O T T O L E N G T H_{t}$, and the duration of Ottoman military activities elsewhere that began in $t, O T H E R L E N G T H_{t}$. Nonetheless, as an additional robustness check, I estimated equation (40) using data with the five-year averages of the dependent and independent variables. The results are shown in columns (7), (8) and (9) of Table 4. The impact of Ottoman military conquests elsewhere and its domestic civil unrests one period lagged, OTHEROTTOMAN $N_{t-1}$, had a strong and positive impact on whether violent feuds in continental Europe were intense or not. This effect is robust to the correction for outliers, the heteroskedasticity in the error terms and the inclusion/exclusion of various control variables. The OTHEROTTOMAN $N_{t-1}$ variable always comes in with the predicted positive sign and it is significant at the five percent confidence level in the first two columns and at the ten percent level in the specification in column (9). The variable OTTOMAN is not statistically significant in any of the regressions reported although it comes in with the expected negative sign in all three estimates.

[Table 4 about here.]

The empirical results so far support the idea that the Ottoman threat induced Europeans to cease their own hostilities and perhaps even cooperate among themselves to thwart the Ottoman Empire's threat to the continent. As a more direct test of the hypothesis that the Protestant Reformation was aided and abated by the Ottomans' European aspirations, I examined whether Ottoman military excursions had a direct impact on the likelihood of the Protestant Reformers and the Catholic Counter-Reformers engaging in violent feuds. In Table 5, I report the results derived from a Probit estimation in which I regressed a dummy variable for Protestant-Catholic Wars over five-year 
periods between 1450 and 1700 on the standard explanatory variables I employed in the previous tables. As shown in columns (1) through (6), the number of Ottomans military engagements in Europe, OTTOMAN , exerted a negative impact on the likelihood of Catholic-Protestant feuds in all specifications and this effect is statistically significant at the 6 percent and 1 percent levels in two of the three robust errors specifications presented in columns (4) through (6). As before, there is some indication that this negative influence was decreasing over time between 1450 and 1700. However, in line with some of my earlier findings that the impact of Ottoman's feuds elsewhere had a statistically weaker impact on intra-European conflicts in general, the influence of Ottomans' military activities in other regions and their domestic unrests, OTHEROTTOMAN , had a negative (instead of the predicted positive) influence on the likelihood of ProtestantCatholic clashes in Europe. In two empirical specifications this effect was also statistical significant.

[Table 5 about here.]

\section{Relevant Historical Facts}

\subsection{The Ottoman Threat and the Protestant Reformation}

As mentioned above, the Ottoman Empire peaked in strength, influence and military might late in the 15 th century and the early part of the 16th century. This is a time period that coincides with some key events in the history of the Protestant Reformation. According to the model I sketched out above, the proliferation of the Lutheran movement was, at least in part, due to the Ottoman threat to Western Europe. A number of historians, in fact, have established such a link (see Benz, 1949, Fischer-Galati, 1959, Setton, 1962, Coles, 1968, Inalcik, 1970, Max Kortepeter, 1972, Shaw, 1976, Goffman, 2002, and MacCulloch, 2003).

Some of these authors have particularly emphasized how the Ottomans' European presence factored in the strategic bargaining between the Holy Roman Emperor Charles V, the King of the Hapsburgs Ferdinand I, and the Catholic Pope on the one hand and the leaders of German Protestant movement on the other. The give and take between the two camps revolved extensively around Ferdinand's need for manpower to fight the Ottoman 
Turks in exchange for temporary peace and even the Church's official recognition of Protestantism. One of the main themes that emerges from the historical analyses of the period is that both sides were very cognizant of the Ottomans' aspirations and swift gains in Europe. This manifested itself in two ways.

First it made it fairly urgent for both the Pope-Charles-Ferdinand nexus and the Protestants to cooperate and deflect this threat. In discussing this point, Shaw (1976) notes "...what [the Ottoman Sultan] Suleiman had done was to shock Austria and most of Europe by the depth of his penetration, causing Charles to make concessions to the Protestants in Germany to gain their support, a major factor in the subsequent survival and expansion of the Lutheran movement throughout western Europe." Goffman (2002) states "It is certain that the Ottoman threat as much as the dynastic claims and political ambitions in Italy distracted Charles V from his declared intent of crushing the Protestant revolt to his north." According to Coles (1968), "With Suleiman's armies at the gates of Vienna and his navies terrorizing the central and western Mediterranean, the traditional frontier had collapsed. The Turks no longer represented a serious nuisance but a deadly danger." MacCulloch (2003), after emphasizing the same point, moves on to stress that "The trail of catastrophe [left in the wake of the Ottomans in Eastern Europe] signaled [to the Christians in western and central Europe] the failure of the crusading enterprise on Europe's southern and eastern flanks, where crusades had achieved so many military advances and annexation of territory against Islam." Fischer-Galati (1959) notes "Since [the Ottoman Sultans] Bayezit and Selim spent most of their reign either in Istanbul or fighting in the Middle East, the Emperor thought of exploiting this situation to strengthen Eastern Europe against [the Turks]. These plans...could not be executed without the help of dependable allies, as the Turks were much more formidable than the mercenaries of the Venetians or the French...To obtain support from the West, Maximilian [Charles V's predecessor] turned once more to the Diets...He was not altogether unjustified in asking their assistance, as some Germans at least seemed interested in undertaking a crusade against the "enemy of the faith." 24

Second, the Ottomans' lopsided victories against the Hapsburgs and in particular

\footnotetext{
${ }^{24}$ For more reference on the topic, consult Charriere (1848), Ursu (1908) and Zinkesien (1854), which Fischer-Galati provides as his original sources in French and German.
} 
their eastern possession, the Hungarian Empire, in the 1520s turned into a bargaining chip for the young Protestant movement; it capitalized on the Hungarian King Ferdinand I's persistent need and demand for soldiers in order to extract strategic concessions from the Catholic Church and the Holy Roman Emperor. On this point, Inalcik (1970, p. 38) comments "...at first Luther and his adherents followed a passive course, maintaining that the Ottoman threat was a punishment from God, but when the Turkish peril began to endanger Germany the Lutherans did not hesitate to support Ferdinand with military and financial aid; in return they always obtained concessions for Lutheranism. Ottoman intervention was thus an important factor not only in the rise of national monarchies, such as in France, but also in the rise of Protestantism in Europe." Along the same lines, Fischer-Galati (1959, p. 9) provides an extensive documentation of the bargaining between the House of the Hapsburgs and the Diet of Nurnberg, representing the early Protestant movement between the 1520s and 1550s. In elaborating on the meeting of the Diet at Worms in 1521, he notes "From as early as 1521, Ferdinand showed grave concern over the Turkish position in Eastern Europe. He realized that the renewed Ottoman aggression, if left unchecked, could bring disaster to Hungary and even perhaps Germany and the Hapsburgs' Austrian possessions...At least until 1526, Ferdinand believed that Hungary could be saved if aid could be secured; hence, from 1521 until the battle of the Mohacs [in 1526] he was a fervent advocate of assistance to Hungary."

Further historical accounts make it clear that Ferdinand could not muster enough help from his brother-in-law Charles V, who was spending his resources in the West to confront the French Emperor Francis and the Italian city-states. As a result, Ferdinand was forced to ask for the assistance of Germans, who were reluctant at first to contribute funds or manpower to the House of the Hapsburgs. Their stance began to change, however, as the Turkish gains in Europe accumulated and Ferdinand became more desperate. On this topic, Fischer-Galati (1959, pp. 19-35) notes:

"By 1522 the Hungarian situation had worsened and the Turks had captured Belgrade... Before 1524 the religious and the Turkish questions were basically separate issues; however, it was clear to the German Diets that the religious question, though not directly associated with the Turkish one, took precedence over it...By the summer of 1526, when a new Diet met at 
Speyer the Hungarian situation had become critical. The Turks were about to launch a decisive campaign against [Hungary] and Ferdinand was gravely concerned...The Diet, however, was not swayed by his arguments...The estates declined to consider the question of assistance to Hungary before solving the German religious problem...[Ferdinand's] alternatives were limited: he could either accede to the wishes of the estates or dissolve the Diet. Turkish pressure on Hungary was too great for him to choose the latter alternative; therefore he reluctantly agreed to the former." 25

The subsequent negotiations between the Protestants and Ferdinand-Charles reflected persistent attempts by the Protestants to link the provision of funds and men to Hungary with the resolution of their religious conflict with the Catholic Church. At the same time, Ferdinand's main concern was to get the Diet to commit troops and funds in defence of Hungary without yielding too many concessions to the Protestants in exchange. Their fruitless wrangling lasted until 1529 when the Ottomans put Vienna under siege. The Ottomans move against the Hapsburgs' Austrian possessions was too big of a move to keep the two sides entrenched in their own positions any longer. As a result, "Germans, irrespective of religious affiliation, prepared to defend the Empire against the Infidel. All these factors convinced the Protestants that they could not withhold their support, and they participated in the campaign that ended with the Turkish withdrawal from Vienna. Disregarding factional interests, the Protestants rallied to the defence of the Empire in 1529. But this was the last time that they joined in anti-Turkish hostilities without first securing concessions in religious matters. After the siege of Vienna, Protestantism and the question of assistance against the Turks became more and more closely interrelated." (Fischer-Galati, 1959, p. 35). Max Kortepeter (1972, p. 196) makes it clear that the attempts to link the Protestants' recognition with the Ottoman threat continued well after the with the Peace of Augsburg in 1555 and into the 17th century: "...the Imperial Reichstag of the German Nation opened on February 3, 1604. The occasion was a bitter one because the majority of its members were Protestant. The Hapsburgs and the Papacy had carried the principal burden of fighting the Ottomans;

\footnotetext{
${ }^{25}$ For more reference on the topic, consult Kluckhohn (1893), which Fischer-Galati lists as his original source in German.
} 
moreover most of the anti-Protestant or anti-Hungarian decrees had originated with Emperor Rudolph and his entourage. Now it was Archduke Matthias who was caught in the middle. He had to make a plea for subsidies to a Reichstag made hostile by the senseless act of Rudolph and his military commanders. The Reichstag lost no time in drafting twenty-one articles to ensure the security of person and property and the free practice of religion in Hungary."

Of course, not all Europeans were equally alarmed and ready to set aside their intra-European differences due to the Ottomans' military and political rise. In particular, Francis, the French Emperor at the time, was more ready to cooperate with the Ottoman Turks than either the House of the Hapsburgs, the Pope or the Roman Emperor himself. In 1535, he signed a treaty with Suleiman the Magnificent which in effect "permitted the French to carry on trade throughout the Ottoman Empire, by payment of the same dues to the Sultan as were paid by the Turks themselves... [The treaty] granted complete religious liberty to the French in the Ottoman Empire, with the right to keep guard over the holy places, and amounted in effect to a French protectorate over all Catholics in the Levant. It put an end to the commercial predominance of Venice in the Mediterranean, and obliged all Christian ships-with the exception of those of the Venetians-to fly the French flag as a guarantee of protection." ${ }^{26}$ Given the empirical discussion above and the historical record, there are two potential explanations for Francis I's readiness to cooperate with the Ottomans and break ranks with the Hapsburgs and the Pope. First, Francis and the Holy Roman Emperor, Charles V, had their own long running territorial and personal disputes. The Houses of the Hapsburgs and the French mutually claimed several areas in Europe and the animosity between Francis and Charles stemmed from Charles' imperial selection which was contested by Francis. ${ }^{27}$ Second, the Ottomans' Eastern European aspirations were more of an urgent geographical threat to the Hapsburg possessions, such as Hungary and Austria, than it was to Francis and the French. ${ }^{28}$

\footnotetext{
${ }^{26}$ Kinross, (1977, p. 204).

${ }^{27}$ Anderson, (1967, p. 58).

${ }^{28}$ As empirical estimates in columns (4) through (6) of Table 4 imply, the negative effect of Ottomans' military activities in Europe on intra-European feuds decreased with geographical distance from the Ottoman Empire.
} 


\subsection{The Protestant Reformation and European Ecclesiastical Institutions}

The impact of the emergence and spread of Protestantism in Europe in the 16th and 17th centuries on the continent's economic revolution in the 18th century has been extensively debated. As is well known, the origins of this debate can be traced back to Weber (1930) who subscribed to the view that Protestantism-particularly its offshoot Calvinism-had "cultivated an intense devotion to one's work or 'calling' in order to assure oneself that one had in fact been selected for salvation." ${ }^{29}$ According to Weber, Calvinism had generated this transformation by espousing the view that seeking material pursuits through work was an alternative form of service to God. Whether the "Protestant work ethic" had indeed something to do with the changing attitudes towards work and commercial activities in Europe and it played a role in the Industrial Revolution of the continent in the 18th century has been-and continues to be-hotly debated. ${ }^{30}$ However, this debate has revolved mostly around whether subscribing to Protestantism itself imbues the individual with certain attributes more commensurate with capitalism. As such, most attempts to unearth the impact of Protestantism on commercialization, capitalism or industrialization has focused on whether capitalist institutions emerged first in places where Protestantism prospered, such as the United Kingdom and Northern Germany, and their development lagged in other places, like Italy, parts of southern Germany and the low countries, where Catholicism prevailed. The short answer to this turned out to be no; capitalist institutions were developed swiftly and effectively in some Catholic parts of continental Europe too, either preceding the Industrial Revolution or alongside with it as a by product. ${ }^{31}$ In some of its more sophisticated forms, these investigations attempted to discern the influence of Protestants in the commercial activities of predominantly Catholic areas. For example, in discussing why the Industrial Revolution began in the United Kingdom despite the fact that it is regarded as the least 'Protestant' of

\footnotetext{
${ }^{29}$ Rosenberg and Birzdell (1986), p. 129.

${ }^{30}$ For instance, Mokyr (1990 and 2002) dismisses this link by noting that the Counter-Reformation era was probably as bigoted a period as the pre-Reformation era. However, Rosenberg and Birzdell (1986) are more sympathetic to this view and discuss in detail.

${ }^{31}$ There is an ongoing debate about the development of institutions and the timing of the Industrial Revolution. According to the "institutions" school espoused by North, Acemoglu et al. and Rodrik et al. institutional development precedes economic growth and development. Nonetheless, as some papers such as Keller and Shiue (2005) point out, institutional development may accompany economic development and not precede it.
} 
all Protestant countries, Rosenberg and Birdzell propose that it might have had something to do with the disproportionate representation of the Calvinist Scotch in British business. $^{32}$

There is a very important difference between these arguments and the one I have developed above: I emphasize that the acceptance and spread of Protestantism in Europe in the 16th and 17th centuries ended the millennium-and-a-half long ecclesiastical monopoly of Catholicism in the West European Christian community. And given the conservative and interventionist leanings of the Catholic Church up until then, the religious competition Protestantism brought to Europe produced less ecclesiastical involvement in commercial activity. This result is in the spirit of Hotelling's spatial competition model in which more competition yields moderation. ${ }^{33}$ Indeed, Barro and McCleary (2003, 2005) apply the Hotelling concept to the contemporary religion markets and find that less monopoly power and more secularization (defined strictly to cover states without official religions and less regulation of religious activities) is good for economic progress.

Some economists and historians have indeed pointed out the role of Protestantism in generating more religious competition in Europe and affecting its economic transformation primarily through that channel. In discussing this issue, Rosenberg and Birdzell (1986, pp. 128-132) first elaborate on the role of Protestantism in developing a "European" moral code of conduct that is more commensurate with commerce. Nonetheless, they continue to note:

"Protestantism sanctioned a high degree of individual responsibility for moral conduct and reduced the authority of the clergy; and Protestant merchants were able to free themselves of clerical constraints which they found incompatible with their own experience. Under the circumstances, it would have been too much to expect the Catholic clergy to continue to stress doctrines which could only turn prosperous parishioners toward Protestantism. More and more, the religious world came to concede that what seemed right within the world of commerce was right for that world...Thus, religious authori-

\footnotetext{
${ }^{32}$ Rosenberg and Birzdell (1986), p. 131.

${ }^{33}$ This is not to suggest that religious competition ought to automatically produce a separation of the church and the state. See the discussion on page 5 for more detail.
} 
ties, whatever judgments they might pronounce over the conduct of business affairs, gradually abandoned the position that the day-to-day conduct of business ought to be regulated by, or be directly subject to, ecclesiastical authority. In the course of the sixteenth and seventeenth centuries, the business sphere was, in a word, secularized."

Furthermore, one of the main thrusts of Martin Luther was his emphasis on the laity's responsibility to study and personally examine the Scripture for themselves. As such, Protestantism had two discernible, long-term effects on the European society and its organization. First, it clearly empowered the individual and emphasized his personal responsibility as superior over ecclesiastical regulations and regimentations. According to Hillerbrand (1968), "The point of the Protestant proclamation was that religion was to be personal and creative. It called for personal involvement, not merely the affirmation of the dogma of the church or the external participation of its rites. It also called for the bold scrutiny of theological tradition and the willingness to reject it where it did not seem to be in harmony with the biblical message...The Reformation was hardly the cradle of the modern world-in a variety of ways its questions were medieval questionsLuther's plea at the Worms was hardly a plea for religious tolerance of the autonomy of conscience, and Calvin's economic thought was hardly the paradigm of Adam Smith. This must not obscure the fact, however, that these and many other "modern" notions made their first appearance during the sixteenth century, and the Reformation did its share in stimulating them: Protestantism stressed the centrality of the individual; sought to reduce the intervention of political power in ecclesiastical affairs; cast the glow of "vocation" over formerly menial undertakings; and raised the spirit of free, personal, and creative inquiry. All this could not help but change the face of society."

Second, the Lutheran calls for the individuals' study and reading of the Bible spurred a greater emphasis on literacy as well as various interpretations of the Scripture with the translation and the printing of the Bible in the vernacular instead of its original Latin. In this respect, one can argue that Protestantism did to Christianity what the educational reforms between 64 A. D. and 200 A. D. did to Judaism in promoting human capital accumulation via the reading and study of religious texts (see Botticini and Eckstein, 2005a and 2005b). In expounding on this idea, Hillerbrand (1968) notes that 
about one million copies of Luther's tracts had been published by 1523 and that the literature produced by the Reformation scholarship-led by the preeminent figures of the time such as Luther, Zwingli and Calvin as well as other minor reformers such as Bucer, Melanchthon and Carlstadt-would not have been published had there not been a sufficient demand for it.

Others have emphasized that perhaps the most important legacy of the recognition of Protestantism and its various offshoots by the Catholic Church in the 16th century was greater social tolerance in Europe. To be sure, such tolerance emerged only after brutal Reformation and Counter-Reformation wars which provided one of the greatest motives for killing in continental Europe during the 16th and 17th centuries and, according to the empirical evidence I presented above, heightened when the Ottoman threat ebbed. That noted, once the Ottoman threat aided the survival of Protestantism in its infancy and it became clear after its official recognition in 1555 that the Counter Reformation Wars would not be able to reclaim the lands lost to Protestantism in central and Northern Europe, religious tolerance became a norm: MucColloch (2003) states,

"Here it is possible to argue that the most significant contribution of the two Reformation centuries to Christianity was the theory and practice of toleration, although it would be possible to argue that the contribution was inadvertent and reluctant. Christianity's previous record on toleration, either of Christian deviance or of other religions, might kindly be termed unimpressive. The eastern Churches (the Orthodox, the Copts, and other Churches of Monopyhsite or Nestorian belief) generally have a better record than the Latin West, but that has been forced on them by circumstance: Power was taken out of their hands by the Muslim invasions and they have had much less chance than the steadily more centralized Latin Church of being successfully intolerant...This dismal record began to change in the Reformation, though once more in the first instance through force of circumstances, as the rival bidders for a monopoly on the expression of Christianity found that they could not impose that monopoly." 


\section{Conclusion}

I claim in this paper that the Ottoman Empire had a lot to do with how the European continent evolved politically and ecclesiastically in the 15th and 16th centuries. My main argument is that institutions evolve endogenously and that, at least historically, international patterns of conflict and cooperation have exerted as much influence on institutions as countries' domestic characteristics or their internal socio-political struggles.

In making this point I rely on some ideas laid out by Wright who asserts that societies have evolved over time to reflect more and more complexity and interdependence between heterogeneous cultures and social groups. The main reason for this is that conflict and survival has been a constant in the history of humankind and, when faced with extraordinary external threats, societies have adapted to learn to cooperate with and tolerate the existence of other cultures-even if they might have had a long history of animosity and conflict-to thwart and deflect such threats.

I incorporate this idea into a model of conflict and appropriation where cultural/religious affinity helps two social groups to cooperate more easily. That is, if various social groups are in conflict over the property claims on productive resources and they begin to face an external threat by a potentially stronger rival who subscribes to a different social code, the groups' survival hinges upon successful cooperation to thwart the external threat. Successful cooperation and coordination is more easily achieved among social groups when they share a common social, ethnic or religious code. Of course, cooperation will not ensure that the external threats are successfully deflected. But conditional on the survival of the society, it can promote coexistence.

The simple model I developed above then suggests that the intensity and magnitude of conflict among the Christian populations of Europe in the late-middle ages and the Reformation period was related negatively to the threat of offensive actions by the Ottoman Empire on the continent. And as a corollary, they were related positively to the degree to which the Ottomans were distracted by other endeavours, such as carrying out military offensives against other non-European foes or trying to subdue civil discords. Utilizing a comprehensive dataset on violent conflicts for a three-and-a half century time period between the 14th and the 18th centuries, I find some empirical support for the idea that Ottoman military engagements in continental Europe lowered 
the number and extent of violent conflicts among the European states themselves, while Ottoman military actions in other regions or domestic civil discords raised them.

On this basis, I then argued that the survival and official recognition of Protestantismsubsequently of Zwinglianism, Anabaptism and Calvinism too-influenced "European institutions" because it generated religious pluralism and sustained a competition between Catholicism, Protestantism, and the offshoots of the latter in the gradual removal of the influence of religion from mercantile activity. 


\section{References}

Acemoglu, D. (2004). "Why Not a Political Coase Theorem? Social Conflict, Committment and Politics," Journal of Comparative Economics, December.

Acemoglu, D., S. Johnson, and J. Robinson. (2001). "The Colonial Origins of Comparative Development," American Economic Review, 91, 1369-1401.

Acemoglu, D., S. Johnson and J. Robinson. (2005). "The Rise of Europe: Atlantic Trade, Institutional Change, and Growth," American Economic Review.

Acemoglu, D. and J. Robinson. (2005). Economic Origins of Dictatorship and Democracy, (Cambridge University Press, Cambridge), September.

Alesina, A. and E. Spolaore. (2006). "Conflict, Defense Spending, and the Number of Nations," European Economic Review, forthcoming.

Anderson, C. S. (1967). Augsburg Historical Atlas of Christianity in the Middle Ages and Reformation, (Minneapolis, MN: Augsburg Publishing House).

Arrunada, B. (2005). "Specialization and Rent-Seeking in Religion: The Case of Confession," Universitat Pompeu Fabra, unpublished manusrcipt.

Barro, R. and R. McCleary. (2003). "Religion and Economic Growth," American Sociological Review, October.

Barro, R. and R. McCleary. (2005). "Which Countries Have State Religions?" Quarterly Journal of Economics, forthcoming.

Benz, E. (1949). Vittenberg und Bizanz, (Marburg).

Botticini, M. and Z. Eckstein. (2005a). "Jewish Occupational Selection: Education, Restrictions, or Minorities?," Journal of Economic History, 65:4, December.

Botticini, M. and Z. Eckstein. (2005b). "From Farmers to Merchants, Voluntary Conversions and Diaspora: A Human Capital Interpretation of Jewish History," University of Minnesota, unpublished manusrcipt.

Brecke, P. (1999). "Violent Conflicts 1400 A.D. to the Present in Different Regions of the World," 1999 Meeting of the Peace Science Society, unpublished manusrcipt. 
Brecke, P. (in progress). "The Conflict Dataset: 1400 A.D. - Present," Georgia Institute of Technology.

Charriere, E. (1848). Negociations de la France dans le Levant, ed., (Paris).

Cioffi-Revilla, C. (1996). "Origins and Evolution of War and Politics," International Studies Quarterly, 40 (1), March, 1-22.

Coles, P. (1968). The Ottoman Impact on Europe, (New York, NY: Harcourt, Brace \& World, Inc. Publishers).

The Euro Atlas Shop, The Euro Atlas, http://www.euroatlas.com.

Faroqhi, S. (2004). The Ottoman Empire and the World Around It, (London: I. B. Tauris Publishers).

Fischer-Galati, S. A. (1959). Ottoman Imperialism and German Protestanism, 15211555, (Cambridge, MA: Harvard University Press).

Fletcher, R. (2003). The Cross and the Crescent: Christianity and Islam from Mohammad to the Reformation, (New York, NY: Viking, Penguin Group).

Frazee, C. A. (1983). Catholic and Sultans: The Church and the Ottoman Empire, 1453-1923, (Cambridge: Cambridge University Press).

Glaeser, E. L., and B. I. Sacerdote. (2002). "Education and Religion." Harvard University, unpublished manuscript.

Glaeser, E. L., R. La Porta, F. Lopez-de-Silanes, and A.Shleifer. (2004). "Do Institutions Cause Growth?" Journal of Economic Growth 9(3): 271-303.

Goffman, D. (2002). The Ottoman Empire and Early Modern Europe, (Cambridge: Cambridge University Press).

Goodwin, J. (2000). Lords of the Horizon: A History of the Ottoman Empire, (New York: Owl Books).

Greif, A. (forthcoming). Institutions: Theory and History, (Cambridge: Cambridge University Press). 
Grossman, H. I. (1994). "Production, Appropriation, and Land Reform," American Economic Review, 84(3), June, 705-12.

Grossman, H. I. and M. Kim. (1995). "Swords or Plowshares? A Theory of the Security of Claims to Property," Journal of Political Economy, 103(6), December, 12751288.

Grossman, H. I. and M. Iyigun. (1995). "The Profitability of Colonial Investment," Economics \& Politics, 7:3, November, 229-24.

Grossman, H. I. and M. Iyigun. (1997). "Population Increase and the End of Colonialism," Economica, 64(3), August, 483-493.

Guiso, L., P. Sapienza, and L. Zingales. (2003). "People's Opium? Religion and Economic Attitudes." Journal of Monetary Economics, 50 (1), 225-82.

Guiso, L., P. Sapienza, and L. Zingales. (forthcoming). "Does Culture Affect Economic Outcomes?" Journal of Economic Perspectives.

Haavelmo, T. (1968). A Study in the Theory of Economic Evolution, (Amsterdam: North-Holland).

Hafer, C. (2006). "On the Origins of Property Rights: Conflict and Production in the State of Nature," Review of Economic Studies, forthcoming.

Hill, C. (1967). Reformation to Industrial Revolution: The Making of Modern English Scoiety, Vol. I, 1530-1780, (New York: Random House).

Hillerbrand, H. (1968). The Protestant Reformation, (New York: Harper Collins).

Hirshleifer, J. (1991)."The Paradox of Power," Economics \&3 Politics, 3:3, November, 177-200.

Hotelling, H. (1929). "Stability in Competition," Economic Journal, 39:1, March, 41-57.

Iannaccone, L. R. (1992). "Sacrifices and Stigma: Reducing the Free-Riding in Cults, Communes and Other Collectives." Journal of Political Economy 100 (2), April, 271-91. 
Inalcik, H. (1973). The Ottoman Empire: The Classical Age, 1300-1600, (London).

Iyigun, M. (in progress). "Ottomans and the Rise of European Colonialism," University of Colorado, unpublished manuscript.

Jacob, J. R. (1983). Henry Stubbe, radical Protestantism and the early Enlightenment, (Cambridge: Cambridge University Press).

Kafadar, C. (1996). Between Two Worlds: The Construction of the Ottoman State, reprinted edition, (Berkeley, CA: University of California Press).

Karpat, K. (1974). The Ottoman State and its Place in World History, ed., (Leiden).

Keller, W. and C. H. Shiue. (2004). "Markets in China and Europe on the Eve of the Industrial Revolution," NBER Working Paper No: 10778, September.

Kinross, L. (1979). Ottoman Centuries, (New York, NY: Harper Perennial).

Kluckhohn, A. (1893). Deutsche Reichstagsakten unter Karl V, ed., (Gotha).

Kuran, T. (2004a). "The Economic Ascent of the Middle East's Religious Minorities: The Role of Islamic Legal Pluralism," Journal of Legal Studies, 33, June, 2003, 475-515.

Kuran, T. (2004b). "Why the Middle East Is Economically Underdeveloped: Historical Mechanisms of Institutional Stagnation," Journal of Economic Perspectives, 18, Summer, 71-90.

Kuran, T. (2005). "The Logic of Financial Westernization in the Middle East." Journal of Economic Behavior and Organization, 56 (April 2005): 593-615.

MacCulloch, D. (2003). The Reformation: A History, (New York, NY: Viking).

Max Kortepeter, C. (1972). Ottoman Imperialism During the Reformation: Europe and the Caucasus, (New York: New York University Press).

McEvedy C, Jones R (1978) Atlas of World Population History. Facts on File, New York.

McNeill, W. (1984). The Pursuit of Power : Technology, Armed Force, and Society since A.D. 1000, (Chicago, IL: University of Chicago Press). 
Mokyr, J. (1990). The Lever of Riches, (New York: Oxford University Press).

Mokyr, J. (2002). The Gifts of Athena: Historical Origins of the Knowledge Economy, (Princeton: Princeton University Press).

Mokyr, J. (2002). "The Enduring Riddle of The European Miracle: The Enlightenment and the Industrial Revolution," Northwestern University, unpublished manuscipt.

Mokyr, J. (2005). "Mobility, Creativity, and Technological Development: David Hume, Immanuel Kant and the Economic Development of Europe," Northwestern University, unpublished manuscipt.

North, D. (1990). Institutions, Institutional Change and Economic Performance (Political Economy of Institutions and Decisions), (Cambridge: Cambridge University Press).

Pirenne, H. (1937). Mohammed and Charlemange, reprinted edition, 2001, (Dover: Dover Publications).

Pirenne, H. (1956). Economic and Social History of Medieval Europe, (New York: Harvest HBJ).

Richardson, L. F. (1960). Statistics of Deadly Quarrels, (Pittsburgh, PA: The Boxwood Press).

Rodrik, D., A. Subramanian, and F. Trebbi. (2004). "Institutions Rule: The Primacy of Institutions over Geography and Integration in Economic Development," Journal of Economic Growth, 9.

Rosenberg, N and L. E. Birdzell, Jr. (1986). How the West Grew Rich: The Economic Transformation of the Industrial World, (New York, NY: Basic Books).

Setton, K. M. (1962). "Lutheranism and the Turkish Peril," Balkan Studies, III (1), 136-65.

Shaw, S. (1976). History of the Ottoman Empire and Modern Turkey, Vol. 1, (Cambridge: Cambridge University Press).

Skaperdas, S. (1992). "Cooperation, Conflict, and Power in the Absence of Property Rights," American Economic Review, September, 82, 720-39. 
Skaperdas, S. (2005). "The Market for Protection and the Origin of the State," University of California at Irvine, unpublished manuscript, May.

Spolaore, E. and R. Wacziarg. (2006). "The Diffusion of Development," Stanford University, unpublished manuscript.

Temin, P. (1997). "Is it Kosher to Talk about Culture?" Journal of Economic History, 57 (2), June, 267-87.

Tilly, C. (1992). Coercion, Capital and European States: AD 990 - 1992 (Studies in Social Discontinuity), (New York, NY: Blackwell Publishers).

Ursu, J. (1908). La Politique Orientale de Francois I, 1515-1547, (Paris).

Van Den Berg, J. (1999). Religious Currents and Cross-Currents: Essays on Early Modern Protestantism and the Protestant Enlightenment, (Boston: Brill).

Weber, M. (1930). Protestant Ethic and the Spirit of Capitalism, trans. T. Parsons (New York: Scribner and Sons).

Wilkinson, D. (1980). Deadly Quarrels: Lewis F. Richardson and the Statistical Study of War, (Berkeley, CA: University of California Press).

Woods, F. A. and A. Baltzly. (1915). Is War Diminishing? A Study of the Prevalence of War in Europe from 1450 to the Present Day, (Boston, MA: Houghton Mifflin Co.).

Wright, R. (2000). Nonzero: The Logic of Human Destiny, (Vintage Books: New York).

Zinkeisen, J. W. (1854). Drei Denkschriften uber die Orientalische Frage von Papst Leo X, Konig Franz I von Frankreich und Kaiser Maximilian I aus dem Jahre 1517, ed., (Gotha). 


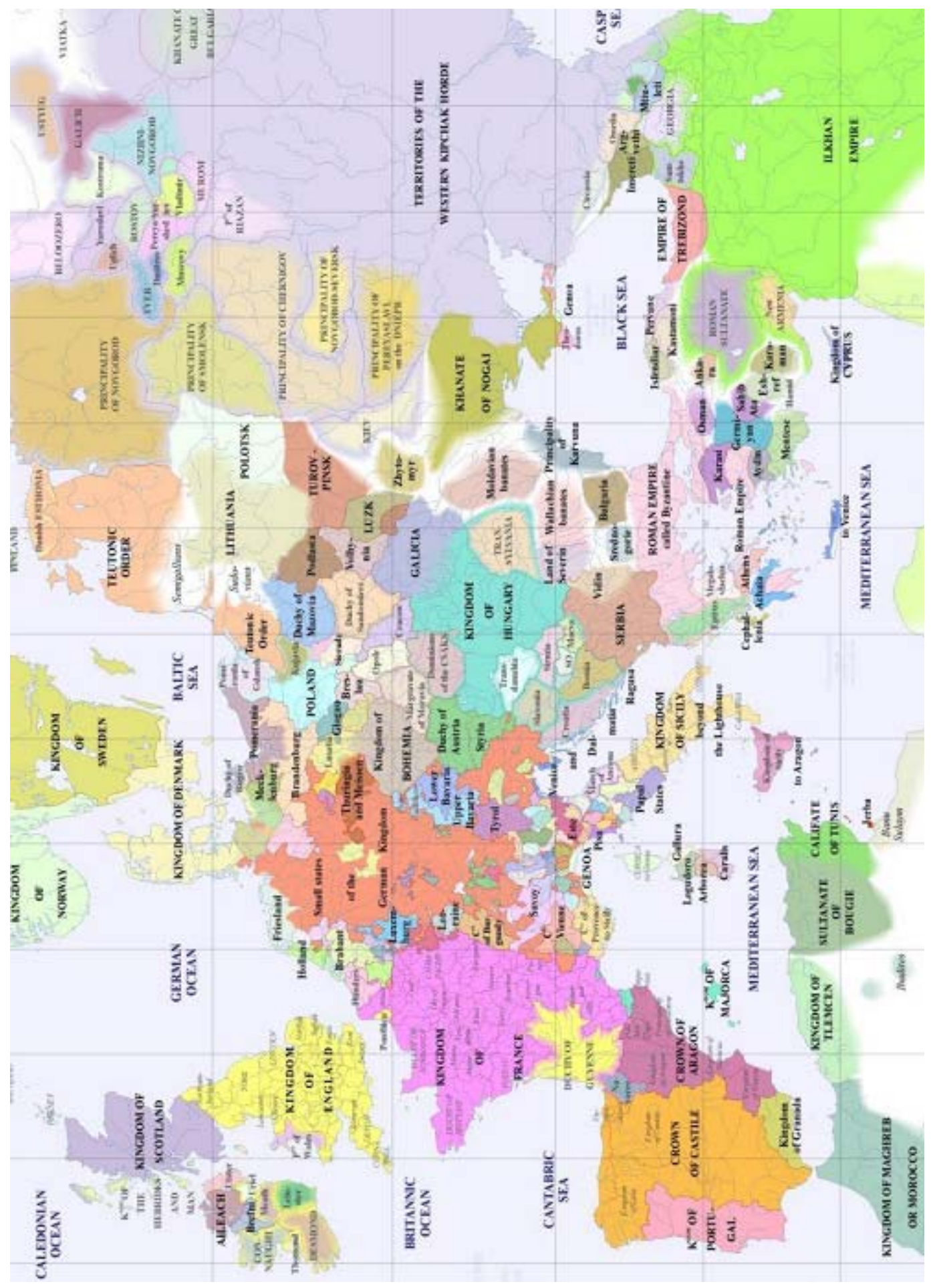

Figure 1: 


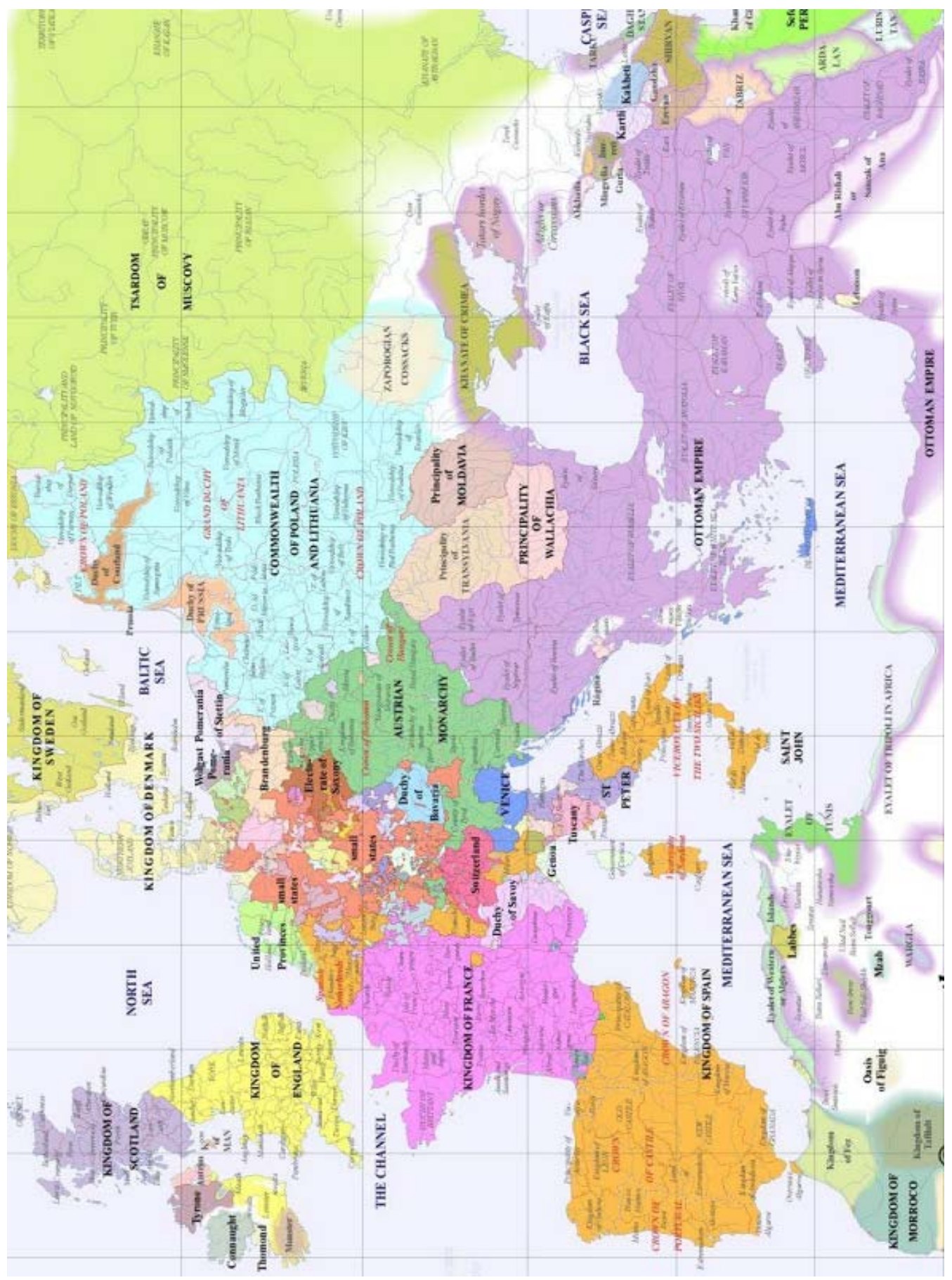

Figure 2: 


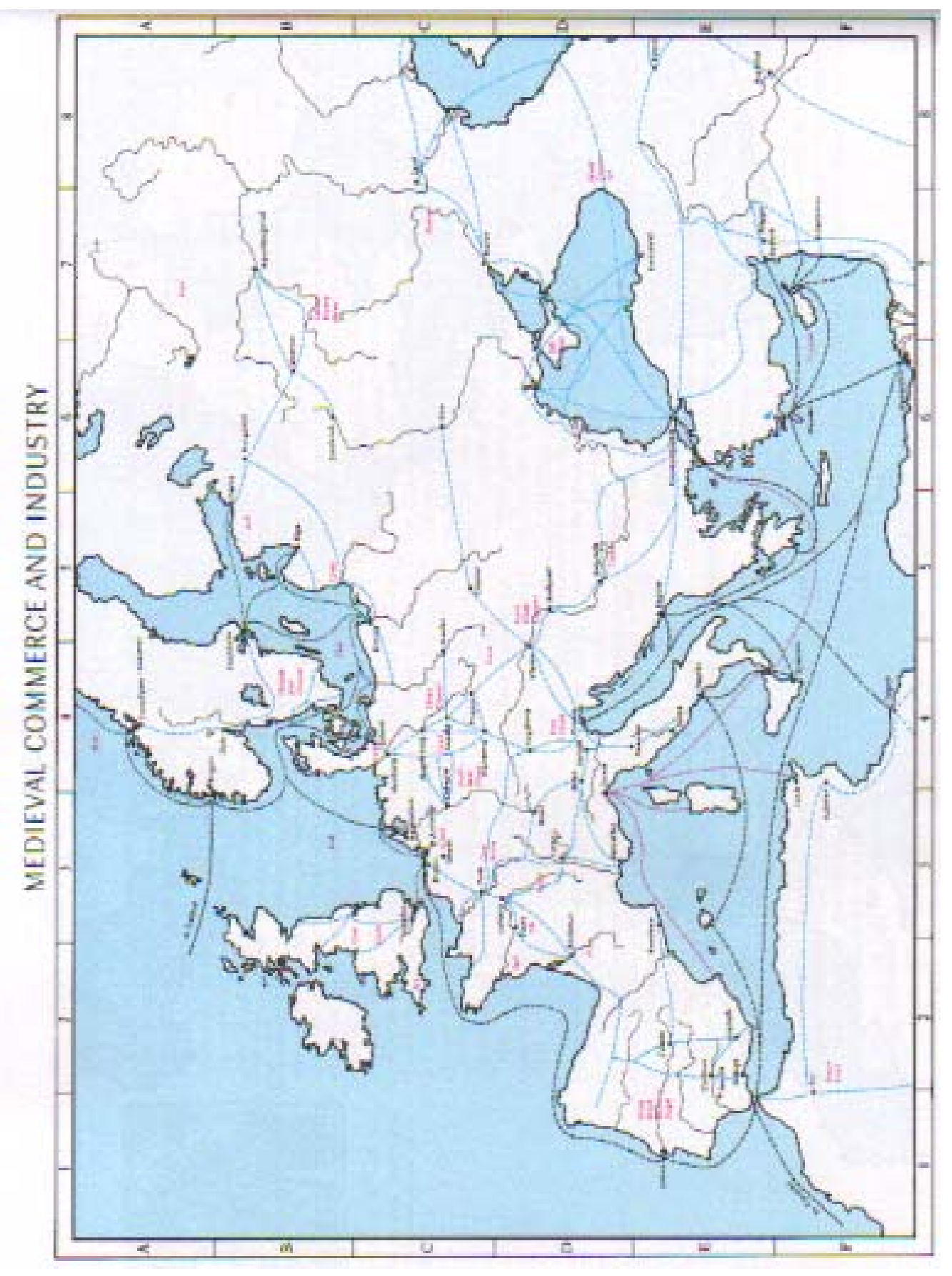

Figure 3: 
Table 1: Descriptive Statistics and the Correlation Matrix

\begin{tabular}{|c|c|c|c|c|c|c|c|c|c|}
\hline \multicolumn{3}{|c|}{ Annual Data } & \multicolumn{7}{|c|}{ The Correlation Matrix } \\
\hline$n=150$ & Mean & St. Dev. & $E U R O$ & OTT. & OTHEROTT. & $E U R O P O P$ & OTTOPOP & $L E N G T H$ & OTTOL. \\
\hline$E U R O P E$ & 1.43 & 1.23 & 1 & $\ldots$ & $\ldots$ & $\ldots$ & $\ldots$ & $\ldots$ & $\ldots$ \\
\hline OTTOMAN & .358 & .626 & -.109 & 1 & $\ldots$ & $\ldots$ & $\ldots$ & $\ldots$ & $\ldots$ \\
\hline OTHEROTT. & .212 & .498 & .098 & .033 & 1 & $\ldots$ & $\ldots$ & $\ldots$ & $\ldots$ \\
\hline$E U R O P O P$ & 83.5 & 11.2 & -.052 & -.187 & .015 & 1 & $\ldots$ & $\ldots$ & $\ldots$ \\
\hline$O T T O M A N P$. & 13.5 & 6.65 & -.010 & -.141 & -.019 & .926 & 1 & $\ldots$ & $\ldots$ \\
\hline LENGTH & 2.78 & 3.65 & .241 & .157 & .075 & -.016 & .061 & 1 & $\ldots$ \\
\hline OTTOLEN. & 1.25 & 2.69 & -.104 & .653 & .123 & -.062 & -.001 & .102 & 1 \\
\hline OTHERLEN. & .491 & 1.53 & .003 & .049 & .580 & -.013 & -.020 & .246 & 140 \\
\hline
\end{tabular}

\begin{tabular}{|c|c|c|c|c|c|c|c|c|c|}
\hline \multicolumn{3}{|c|}{ 5-year Average Data } & \multicolumn{7}{|c|}{ The Correlation Matrix } \\
\hline$n=70$ & Mean & St. Dev. & $E U R O$ & OTT. & OTHEROTT. & $E U R O P O P$ & OTТОРОР & LENGTH & OTTOL. \\
\hline$E U R O P E$ & 6.07 & 3.17 & 1 & $\ldots$ & $\ldots$ & $\ldots$ & $\ldots$ & $\ldots$ & $\ldots$ \\
\hline OTTOMAN & 1.26 & 1.25 & .130 & 1 & $\ldots$ & $\ldots$ & $\ldots$ & $\ldots$ & $\ldots$ \\
\hline OTHEROTT. & .871 & .992 & .173 & -.006 & 1 & $\ldots$ & $\ldots$ & $\ldots$ & $\ldots$ \\
\hline EUROPOP & 94.4 & 20.9 & -.459 & -.428 & .085 & 1 & $\ldots$ & $\ldots$ & $\ldots$ \\
\hline$O T T O M A N P$. & 18.5 & 8.71 & -.203 & -.323 & .140 & .823 & 1 & $\ldots$ & $\cdots$ \\
\hline$L E N G T H$ & 3.45 & 2.23 & .327 & .081 & -.125 & -.171 & -.047 & 1 & $\ldots$ \\
\hline OTTOLEN. & 3.40 & 4.06 & .062 & .300 & .141 & -.143 & .011 & -.162 & 1 \\
\hline OTHERLEN. & 1.96 & 3.09 & .017 & .074 & .266 & -.077 & .027 & -.024 & .185 \\
\hline
\end{tabular}


Table 2: Regressions with Annual Data, 1450 A. D. - 1600 A. D.

Dependent Variable: No. of Continental European Wars per Year

\begin{tabular}{|c|c|c|c|c|c|c|c|c|c|}
\hline & \multicolumn{3}{|c|}{ 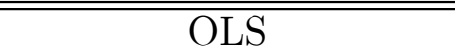 } & \multicolumn{3}{|c|}{ Robust Errors } & \multicolumn{3}{|c|}{ Robust Regression } \\
\hline & 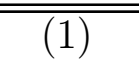 & 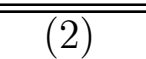 & 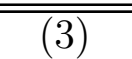 & $\overline{(4)}$ & $\overline{(5)}$ & 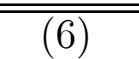 & 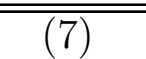 & $\overline{(8)}$ & 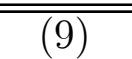 \\
\hline$O T T O M A N_{t}$ & $\begin{array}{l}-.447^{*} \\
(.241)\end{array}$ & $\begin{array}{c}-.504^{*} \\
(.258)\end{array}$ & $\begin{array}{l}-.387 \\
(.258)\end{array}$ & $\begin{array}{l}-.447^{*} \\
(.177)\end{array}$ & $\begin{array}{l}-.504^{*} \\
(.200)\end{array}$ & $\begin{array}{l}-.387^{*} \\
(.209)\end{array}$ & $\begin{array}{l}-.395^{*} \\
(.236)\end{array}$ & $\begin{array}{c}-.432^{* *} \\
(.255)\end{array}$ & $\begin{array}{l}-.488^{*} \\
(.209)\end{array}$ \\
\hline OTHEROTTOMAN & $\begin{array}{l}-.011 \\
(.397)\end{array}$ & $\begin{array}{l}-.149 \\
(.399)\end{array}$ & $\begin{array}{l}.124 \\
(.361)\end{array}$ & $\begin{array}{l}-.011 \\
(.352)\end{array}$ & $\begin{array}{l}-.149 \\
(.383)\end{array}$ & $\begin{array}{l}.124 \\
(.350)\end{array}$ & $\begin{array}{l}-.144 \\
(.389)\end{array}$ & $\begin{array}{l}-.273 \\
(.392)\end{array}$ & $\begin{array}{l}-.256 \\
(.292)\end{array}$ \\
\hline$T I M E$ & $\begin{array}{l}-.017 \\
(.012)\end{array}$ & $\begin{array}{c}-.023^{*} \\
(.011)\end{array}$ & $\begin{array}{l}-.004 \\
(.033)\end{array}$ & $\begin{array}{l}-.017 \\
(.012)\end{array}$ & $\begin{array}{c}.023^{* *} \\
(.012)\end{array}$ & $\begin{array}{l}-.004 \\
(.028)\end{array}$ & $\begin{array}{l}-.010 \\
(.012)\end{array}$ & $\begin{array}{l}-.015 \\
(.012)\end{array}$ & $\begin{array}{l}.005 \\
(.027)\end{array}$ \\
\hline$T I M E * O T T O M A N_{t}$ & $\begin{array}{l}.004 \\
(.003)\end{array}$ & $\begin{array}{l}.006^{* *} \\
(.003)\end{array}$ & $\begin{array}{c}.003 \\
(.003)\end{array}$ & $\begin{array}{l}.004^{* *} \\
(.002)\end{array}$ & $\begin{array}{l}.006^{*} \\
(.002)\end{array}$ & $\begin{array}{l}.003 \\
(.002)\end{array}$ & $\begin{array}{l}.005 \\
(.003)\end{array}$ & $\begin{array}{l}.006^{*} \\
(.003)\end{array}$ & $\begin{array}{l}.004^{* *} \\
(.002)\end{array}$ \\
\hline TIME* OTHEROTTOMAN & $\begin{array}{l}.003 \\
(.003)\end{array}$ & $\begin{array}{c}.007 \\
(.005)\end{array}$ & $\begin{array}{c}.006 \\
(.005)\end{array}$ & $\begin{array}{c}.003 \\
(.005)\end{array}$ & $\begin{array}{c}.007 \\
(.005)\end{array}$ & $\begin{array}{l}.006 \\
(.006)\end{array}$ & $\begin{array}{c}.003 \\
(.005)\end{array}$ & $\begin{array}{l}.007 \\
(.005)\end{array}$ & $\begin{array}{c}.001 \\
(.004)\end{array}$ \\
\hline$E U R O P E_{t-1}$ & $\begin{array}{l}-.211^{*} \\
(.082)\end{array}$ & $\begin{array}{c}-.174^{*} \\
(.080)\end{array}$ & $\begin{array}{l}-.159^{*} \\
(.070)\end{array}$ & $\begin{array}{l}-.211^{*} \\
(.092)\end{array}$ & $\begin{array}{c}.174^{* *} \\
(.089)\end{array}$ & $\begin{array}{l}-.159^{*} \\
(.080)\end{array}$ & $\begin{array}{l}-.209^{*} \\
(.080)\end{array}$ & $\begin{array}{c}-.178^{*} \\
(.078)\end{array}$ & $\begin{array}{l}-.174^{*} \\
(.057)\end{array}$ \\
\hline$E U R O P E P O P_{t}$ & $\begin{array}{l}.047 \\
(.047)\end{array}$ & $\begin{array}{l}.065 \\
(.047)\end{array}$ & $\begin{array}{c}.008 \\
(.067)\end{array}$ & $\begin{array}{c}.047 \\
(.049)\end{array}$ & $\begin{array}{l}.065 \\
(.049)\end{array}$ & $\begin{array}{l}.008 \\
(.059)\end{array}$ & $\begin{array}{l}.020 \\
(.047)\end{array}$ & $\begin{array}{l}.036 \\
(.046)\end{array}$ & $\begin{array}{l}-.002 \\
(.055)\end{array}$ \\
\hline$L E N G T H_{t}$ & $\ldots$ & $\begin{array}{l}.106^{*} \\
(.028)\end{array}$ & $\begin{array}{l}.048^{* *} \\
(.026)\end{array}$ & $\ldots$ & $\begin{array}{l}.106^{*} \\
(.035)\end{array}$ & $\begin{array}{l}.048^{* *} \\
(.026)\end{array}$ & $\ldots$ & $\begin{array}{l}.099^{*} \\
(.028)\end{array}$ & $\begin{array}{c}.025 \\
(.021)\end{array}$ \\
\hline $\mathrm{OTTOLENGTH}_{t}$ & $\ldots$ & $\begin{array}{l}-.046 \\
(.049)\end{array}$ & $\begin{array}{l}-.019 \\
(.046)\end{array}$ & $\ldots$ & $\begin{array}{l}-.046 \\
(.36)\end{array}$ & $\begin{array}{l}-.019 \\
(.031)\end{array}$ & $\ldots$ & $\begin{array}{l}-.051 \\
(.048)\end{array}$ & $\begin{array}{l}-.013 \\
(.037)\end{array}$ \\
\hline OTHERLENGTH $H_{t}$ & $\ldots$ & $\begin{array}{l}-.096 \\
(.083)\end{array}$ & $\begin{array}{l}-.042 \\
(.076)\end{array}$ & $\ldots$ & $\begin{array}{l}-.096 \\
(.081)\end{array}$ & $\begin{array}{l}-.042 \\
(.061)\end{array}$ & $\ldots$ & $\begin{array}{l}-.068 \\
(.081)\end{array}$ & $\begin{array}{c}.003 \\
(.061)\end{array}$ \\
\hline$O T T O M A N_{t-1}$ & $\ldots$ & $\ldots$ & $\begin{array}{l}-.210 \\
(.142)\end{array}$ & $\ldots$ & $\ldots$ & $\begin{array}{l}-.210 \\
(.151)\end{array}$ & $\ldots$ & $\ldots$ & $\begin{array}{c}.023 \\
(.115)\end{array}$ \\
\hline OTHEROTTOMAN $N_{t-1}$ & $\ldots$ & $\ldots$ & $\begin{array}{l}.589^{*} \\
(.179)\end{array}$ & $\ldots$ & $\ldots$ & $\begin{array}{l}.589^{*} \\
(.226)\end{array}$ & $\ldots$ & $\ldots$ & $\begin{array}{l}.120 \\
(.145)\end{array}$ \\
\hline No. of obs. & 150 & 150 & 150 & 150 & 150 & 150 & 150 & 150 & 150 \\
\hline$\overline{R^{2}}$ & .094 & .184 & .416 & .094 & .184 & .416 & $\ldots$ & $\ldots$ & $\ldots$ \\
\hline
\end{tabular}

Note: ${ }^{*},{ }^{* *}$ respectively denote significance at the 5 percent and 10 percent levels. 
Table 3: Results with Annual Data, 1450 A. D. - 1600 A. D.

Dependent Variable: No. of Continental European Wars per Year

\begin{tabular}{|c|c|c|c|c|c|c|c|c|c|}
\hline & \multicolumn{3}{|c|}{$\overline{\mathrm{OLS}}$} & \multicolumn{3}{|c|}{ Robust Errors } & \multicolumn{3}{|c|}{ Robust Regression } \\
\hline & 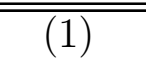 & 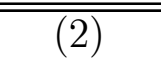 & 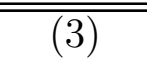 & 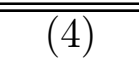 & 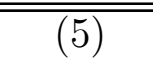 & 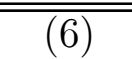 & 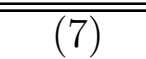 & 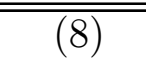 & 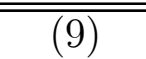 \\
\hline$O T T O M A N_{t-1}$ & $\begin{array}{c}-.688^{*} \\
(.290)\end{array}$ & $\begin{array}{c}-.670^{*} \\
(.283)\end{array}$ & $\begin{array}{c}-.623^{*} \\
(.258)\end{array}$ & $\begin{array}{c}-.688^{*} \\
(.252)\end{array}$ & $\begin{array}{c}-.670^{*} \\
(.255)\end{array}$ & $\begin{array}{r}-.623^{*} \\
(.209)\end{array}$ & $\begin{array}{c}-.577^{*} \\
(.297)\end{array}$ & $\begin{array}{c}-.620^{*} \\
(.288)\end{array}$ & $\begin{array}{c}-.345^{* *} \\
(.213)\end{array}$ \\
\hline OTHEROTTOMAN $N_{t-1}$ & $\begin{array}{l}.623 \\
(.469)\end{array}$ & $\begin{array}{c}.507 \\
(.457)\end{array}$ & $\begin{array}{l}.541 \\
(.412)\end{array}$ & $\begin{array}{l}.623^{*} \\
(.363)\end{array}$ & $\begin{array}{l}.507 \\
(.357)\end{array}$ & $\begin{array}{l}.541 \\
(.355)\end{array}$ & $\begin{array}{l}.552 \\
(.483)\end{array}$ & $\begin{array}{c}.402 \\
(.465)\end{array}$ & $\begin{array}{l}.390 \\
(.343)\end{array}$ \\
\hline TIME & $\begin{array}{l}-.014 \\
(.011)\end{array}$ & $\begin{array}{c}-.019^{* *} \\
(.011)\end{array}$ & $\begin{array}{l}-.006 \\
(.034)\end{array}$ & $\begin{array}{l}-.014 \\
(.011)\end{array}$ & $\begin{array}{c}-.019^{* *} \\
(.011)\end{array}$ & $\begin{array}{l}-.006 \\
(.027)\end{array}$ & $\begin{array}{l}-.011 \\
(.012)\end{array}$ & $\begin{array}{l}-.014 \\
(.012)\end{array}$ & $\begin{array}{c}.008 \\
(.028)\end{array}$ \\
\hline$\overline{T I M E} * O T T O M A N_{t-1}$ & $\begin{array}{l}.006^{* *} \\
(.003)\end{array}$ & $\begin{array}{l}.006^{* *} \\
(.003)\end{array}$ & $\begin{array}{l}.006^{* *} \\
(.003)\end{array}$ & $\begin{array}{l}.006^{*} \\
(.003)\end{array}$ & $\begin{array}{l}.006^{*} \\
(.002)\end{array}$ & $\begin{array}{l}.006^{*} \\
(.002)\end{array}$ & $\begin{array}{l}.006 \\
(.004)\end{array}$ & $\begin{array}{l}.006^{* *} \\
(.003)\end{array}$ & $\begin{array}{l}.005^{* *} \\
(.003)\end{array}$ \\
\hline TIME *OTHEROTTOMAN $N_{t-1}$ & $\begin{array}{c}.001 \\
(.006)\end{array}$ & $\begin{array}{c}.002 \\
(.006)\end{array}$ & $\begin{array}{c}.001 \\
(.006)\end{array}$ & $\begin{array}{c}.001 \\
(.004)\end{array}$ & $\begin{array}{c}.002 \\
(.005)\end{array}$ & $\begin{array}{c}.001 \\
(.004)\end{array}$ & $\begin{array}{c}.000 \\
(.006)\end{array}$ & $\begin{array}{c}.002 \\
(.006)\end{array}$ & $\begin{array}{l}-.001 \\
(.004)\end{array}$ \\
\hline$E U R O P E_{t-1}$ & $\begin{array}{c}-.256^{*} \\
(.078)\end{array}$ & $\begin{array}{l}-.233^{*} \\
(.077)\end{array}$ & $\begin{array}{l}-.190^{*} \\
(.071)\end{array}$ & $\begin{array}{c}-.256^{*} \\
(.087)\end{array}$ & $\begin{array}{c}-.233^{* *} \\
(.083)\end{array}$ & $\begin{array}{l}-.190^{*} \\
(.077)\end{array}$ & $\begin{array}{r}-.248^{*} \\
(.081)\end{array}$ & $\begin{array}{l}-.229^{*} \\
(.079)\end{array}$ & $\begin{array}{r}-.188^{*} \\
(.059)\end{array}$ \\
\hline$E U R O P E P O P_{t}$ & $\begin{array}{c}.035 \\
(.046)\end{array}$ & $\begin{array}{c}.052 \\
(.045)\end{array}$ & $\begin{array}{c}.005 \\
(.068)\end{array}$ & $\begin{array}{c}.035 \\
(.048)\end{array}$ & $\begin{array}{c}.052 \\
(.047)\end{array}$ & $\begin{array}{c}.005 \\
(.059)\end{array}$ & $\begin{array}{c}.023 \\
(.047)\end{array}$ & $\begin{array}{c}.033 \\
(.046)\end{array}$ & $\begin{array}{l}-.015 \\
(.057)\end{array}$ \\
\hline$L E N G T H_{t}$ & $\ldots$ & $\begin{array}{l}.082^{*} \\
(.027)\end{array}$ & $\begin{array}{c}.033 \\
(.026)\end{array}$ & $\ldots$ & $\begin{array}{l}.082^{*} \\
(.034)\end{array}$ & $\begin{array}{c}.033 \\
(.029)\end{array}$ & $\ldots$ & $\begin{array}{l}.098^{*} \\
(.027)\end{array}$ & $\begin{array}{l}.015 \\
(.021)\end{array}$ \\
\hline OTTOLENGTH & $\ldots$ & $\begin{array}{c}-.057^{* *} \\
(.035)\end{array}$ & $\begin{array}{l}-.038 \\
(.043)\end{array}$ & $\ldots$ & $\begin{array}{c}-.057^{* *} \\
(.32)\end{array}$ & $\begin{array}{l}-.038 \\
(.030)\end{array}$ & $\ldots$ & $\begin{array}{l}-.042 \\
(.037)\end{array}$ & $\begin{array}{l}-.016 \\
(.036)\end{array}$ \\
\hline$O T H E R L E N G T H_{t}$ & $\ldots$ & $\begin{array}{c}.013 \\
(.063)\end{array}$ & $\begin{array}{c}.003 \\
(.073)\end{array}$ & $\ldots$ & $\begin{array}{c}.013 \\
(.058)\end{array}$ & $\begin{array}{c}.003 \\
(.059)\end{array}$ & $\ldots$ & $\begin{array}{l}-.006 \\
(.064)\end{array}$ & $\begin{array}{l}-.019 \\
(.061)\end{array}$ \\
\hline$\overline{D I S T A N C E_{t}}$ & $\ldots$ & $\ldots$ & $\begin{array}{l}.001^{*} \\
(.000)\end{array}$ & $\ldots$ & $\ldots$ & $\begin{array}{l}.001^{*} \\
(.000)\end{array}$ & $\ldots$ & $\ldots$ & $\begin{array}{c}.001^{*} \\
(.000)\end{array}$ \\
\hline No. of obs. & 150 & 150 & 150 & 150 & 150 & 150 & 150 & 150 & 150 \\
\hline$R^{2}$ & .166 & .180 & .396 & .166 & .180 & .396 & $\ldots$ & $\ldots$ & $\ldots$ \\
\hline
\end{tabular}

Note: ${ }^{*},{ }^{* *}$ respectively denote significance at the 5 percent and 10 percent levels. 
Table 4: More Results with Annual Data, 1450 A. D. - 1600 A. D. and Five-year Average Data 1400 A. D. - 1700 A. D.

Dependent Variable: No. of Continental European Wars

\begin{tabular}{|c|c|c|c|c|c|c|c|c|c|}
\hline & \multicolumn{3}{|c|}{ 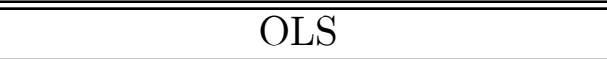 } & \multicolumn{3}{|c|}{ Robust Errors } & \multicolumn{3}{|c|}{ Robust Regression } \\
\hline & (1) & $\overline{(2)}$ & $\overline{(3)}$ & 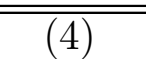 & $\overline{(5)}$ & $\overline{(26)}$ & 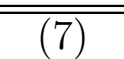 & (8) & $\overline{(9)}$ \\
\hline$O T T O M A N_{t}$ & $\begin{array}{l}-.0006^{* *} \\
(.00037)\end{array}$ & $\begin{array}{l}-.0006^{* *} \\
(.00033)\end{array}$ & $\begin{array}{l}-.0005 \\
(.0003)\end{array}$ & $\begin{array}{l}119.2 \\
(80.3)\end{array}$ & $\begin{array}{l}119.2^{*} \\
(55.5)\end{array}$ & $\begin{array}{l}110.2 \\
(79.9)\end{array}$ & $\begin{array}{l}-.331 \\
(.503)\end{array}$ & $\begin{array}{l}-.331 \\
(.560)\end{array}$ & $\begin{array}{l}-.306 \\
(.583)\end{array}$ \\
\hline OTHEROTTOMAN & $\begin{array}{c}.0003 \\
(.0004)\end{array}$ & $\begin{array}{c}.0003 \\
(.0004)\end{array}$ & $\begin{array}{l}-.0002 \\
(.0004)\end{array}$ & $\begin{array}{c}-95.9 \\
(113.7)\end{array}$ & $\begin{array}{l}-95.9 \\
(99.3)\end{array}$ & $\begin{array}{l}-100.0 \\
(113.2)\end{array}$ & $\begin{array}{c}.764 \\
(.720)\end{array}$ & $\begin{array}{l}.764 \\
(.674)\end{array}$ & $\begin{array}{c}.868 \\
(.834)\end{array}$ \\
\hline TIME & $\begin{array}{c}-.000006 \\
(.00001)\end{array}$ & $\begin{array}{c}-.000006 \\
(.00001)\end{array}$ & $\begin{array}{c}-.000003 \\
(.00001)\end{array}$ & $\begin{array}{l}-2.97 \\
(3.69)\end{array}$ & $\begin{array}{l}-2.97 \\
(4.08)\end{array}$ & $\begin{array}{l}-3.13 \\
(3.67)\end{array}$ & $\begin{array}{c}.159 \\
(.178) \\
\end{array}$ & $\begin{array}{c}.159 \\
(.189) \\
\end{array}$ & $\begin{array}{c}.168 \\
(.207) \\
\end{array}$ \\
\hline$T I M E * O T T O M A N_{t}$ & $\begin{array}{l}.000002^{*} \\
(.000003)\end{array}$ & $\begin{array}{l}.000002^{*} \\
(.000003)\end{array}$ & $\begin{array}{c}.000002 \\
(.000003)\end{array}$ & $\begin{array}{c}.031 \\
(1.00)\end{array}$ & $\begin{array}{c}.031 \\
(.900)\end{array}$ & $\begin{array}{c}.044 \\
(.997)\end{array}$ & $\begin{array}{c}.003 \\
(.017)\end{array}$ & $\begin{array}{c}.003 \\
(.018)\end{array}$ & $\begin{array}{c}.002 \\
(.019)\end{array}$ \\
\hline TIME *OTHEROTTOMAN & $\begin{array}{c}.000007 \\
(.000006)\end{array}$ & $\begin{array}{c}.000007 \\
(.000007)\end{array}$ & $\begin{array}{c}.000007 \\
(.000006)\end{array}$ & $\begin{array}{c}.556 \\
(1.64)\end{array}$ & $\begin{array}{c}.556 \\
(1.37)\end{array}$ & $\begin{array}{c}.549 \\
(1.63)\end{array}$ & $\begin{array}{l}-.003 \\
(.018)\end{array}$ & $\begin{array}{l}-.003 \\
(.018)\end{array}$ & $\begin{array}{l}-.005 \\
(.021)\end{array}$ \\
\hline$E U R O P E_{t-1}$ & $\begin{array}{c}-.138^{* *} \\
(.081)\end{array}$ & $\begin{array}{l}-.138 \\
(.105)\end{array}$ & $\begin{array}{l}-.193^{*} \\
(.076)\end{array}$ & $\ldots$ & $\ldots$ & $\ldots$ & $\begin{array}{l}.262^{*} \\
(.127)\end{array}$ & $\begin{array}{l}.262^{*} \\
(.124)\end{array}$ & $\begin{array}{l}.245^{* *} \\
(.148)\end{array}$ \\
\hline$E U R O P E P O P_{t}$ & $\begin{array}{l}.000007 \\
(.00004)\end{array}$ & $\begin{array}{l}.000006 \\
(.00005)\end{array}$ & $\begin{array}{c}-.000005 \\
(.00005)\end{array}$ & $\begin{array}{c}12.7 \\
(14.8)\end{array}$ & $\begin{array}{c}12.7 \\
(15.4)\end{array}$ & $\begin{array}{c}13.7 \\
(14.8)\end{array}$ & $\begin{array}{l}-.251 \\
(.157)\end{array}$ & $\begin{array}{l}-.251 \\
(.158)\end{array}$ & $\begin{array}{l}-.267 \\
(.182)\end{array}$ \\
\hline$L E N G T H_{t}$ & $\ldots$ & $\ldots$ & $\ldots$ & $\begin{array}{l}-3.47 \\
(8.54)\end{array}$ & $\begin{array}{l}-3.47 \\
(6.31)\end{array}$ & $\begin{array}{l}-3.46 \\
(8.51)\end{array}$ & $\begin{array}{l}.313^{*} \\
(.144)\end{array}$ & $\begin{array}{l}.313^{*} \\
(.147)\end{array}$ & $\begin{array}{l}.320^{* *} \\
(.167)\end{array}$ \\
\hline OTTOLENGTH & $\ldots$ & $\ldots$ & $\ldots$ & $\begin{array}{l}-16.8 \\
(20.8)\end{array}$ & $\begin{array}{l}-16.8 \\
(14.6)\end{array}$ & $\begin{array}{l}-16.6 \\
(20.7)\end{array}$ & $\begin{array}{l}-.021 \\
(.083)\end{array}$ & $\begin{array}{l}-.021 \\
(.072)\end{array}$ & $\begin{array}{l}-.010 \\
(.096)\end{array}$ \\
\hline OTHERLENGTH $H_{t}$ & $\ldots$ & $\ldots$ & $\ldots$ & $\begin{array}{c}14.2 \\
(24.5)\end{array}$ & $\begin{array}{c}14.2 \\
(13.4)\end{array}$ & $\begin{array}{c}14.7 \\
(24.4)\end{array}$ & $\begin{array}{l}-.012 \\
(.114)\end{array}$ & $\begin{array}{l}-.012 \\
(.141)\end{array}$ & $\begin{array}{l}-.027 \\
(.132)\end{array}$ \\
\hline$O T T O M A N_{t-1}$ & $\ldots$ & $\ldots$ & $\ldots$ & $\ldots$ & $\ldots$ & $\ldots$ & $\begin{array}{l}.318 \\
(.270)\end{array}$ & $\begin{array}{l}.318 \\
(.273)\end{array}$ & $\begin{array}{l}.305 \\
(.313)\end{array}$ \\
\hline OTHEROTTOMAN $N_{t-1}$ & $\ldots$ & $\ldots$ & $\ldots$ & $\ldots$ & $\ldots$ & $\ldots$ & $\begin{array}{l}.712^{*} \\
(.325)\end{array}$ & $\begin{array}{l}.712^{*} \\
(.365)\end{array}$ & $\begin{array}{l}.659^{* *} \\
(.376)\end{array}$ \\
\hline No. of obs. & 150 & 150 & 150 & 114 & 114 & 114 & 69 & 69 & 69 \\
\hline$R^{2}$ & .115 & .115 & $\ldots$ & .068 & .068 & .45 & .554 & .554 & $\ldots$ \\
\hline
\end{tabular}

Note: ${ }^{*},{ }^{*}$ respectively denote significance at the 5 percent and 10 percent levels. 
Table 5: The Ottoman Impact on the Protestant-Catholic Violent Confrontations

Dependent Variable: Annual Probability of War, 1450 through 1700

\begin{tabular}{||l|c|c|c|c|c|c||}
\hline \hline & \multicolumn{3}{|c|}{ Probit } & \multicolumn{3}{c||}{ Robust Errors Probit } \\
\hline \hline OTTOMAN & $(1)$ & $(2)$ & $(3)$ & $(4)$ & $(5)$ & $(6)$ \\
& -.442 & -.666 & -4.23 & -.442 & $-.666^{* *}$ & $-4.23^{*}$ \\
& $(.439)$ & $(.534)$ & $(3.66)$ & $(.310)$ & $(.354)$ & $(.980)$ \\
\hline OTHEROTTOMAN $_{t}$ & -.986 & $-1.51^{* *}$ & -4.79 & -.986 & $-1.51^{*}$ & $-4.79^{*}$ \\
& $(.672)$ & $(.856)$ & $(3.54)$ & $(.620)$ & $(.681)$ & $(1.65)$ \\
\hline EUROPE $E_{t}$ & -.390 & -.377 & -.980 & $-.390^{*}$ & $-.377^{*}$ & $-.980^{* *}$ \\
& $(.233)$ & $(.254)$ & $(.946)$ & $(.136)$ & $(.163)$ & $(.514)$ \\
\hline TIME & -.069 & -.061 & -1.16 & -.069 & -.061 & $-1.16^{*}$ \\
& $(.141)$ & $(.160)$ & $(.908)$ & $(.120)$ & $(.139)$ & $(.329)$ \\
\hline TIME* OTTOMAN & .013 & .016 & .099 & .013 & .016 & $.099^{*}$ \\
& $(.012)$ & $(.015)$ & $(.094)$ & $(.010)$ & $(.011)$ & $(.032)$ \\
\hline TIME* OTHROT.t & $.025^{* *}$ & $.035^{*}$ & .073 & $.025^{*}$ & $.035^{*}$ & $.073^{*}$ \\
& $(.015)$ & $(.018)$ & $(.059)$ & $(.013)$ & $(.014)$ & $(.029)$ \\
\hline TIME* EUROPE $E_{t}$ & $.012^{*}$ & $.011^{* *}$ & .033 & $.012^{*}$ & $.011^{*}$ & $.033^{*}$ \\
& $(.006)$ & $(.006)$ & $(.027)$ & $(.003)$ & $(.004)$ & $(.010)$ \\
\hline EUROPEPOP & -.011 & -.021 & .946 & -.011 & -.211 & $.946^{*}$ \\
& $(.124)$ & $(.142)$ & $(.742)$ & $(.104)$ & $(.119)$ & $(.271)$ \\
\hline LENGTH & $\ldots$ & .161 & -.182 & $\ldots$ & $.161^{* *}$ & -.182 \\
& & $(.110)$ & $(.580)$ & & $(.096)$ & $(.191)$ \\
\hline OTTOLENGTH & $\ldots$ & .066 & -.230 & $\ldots$ & .066 & $-.230^{*}$ \\
& & $(.057)$ & $(.236)$ & & $.052)$ & $(.106)$ \\
\hline OTHERLENGTH $H_{t}$ & $\cdots$ & .073 & .533 & $\ldots$ & .073 & $.533^{*}$ \\
& & $(.080)$ & $(.368)$ & & $(.065)$ & $(.122)$ \\
\hline
\end{tabular}

Note: ${ }^{*},{ }^{* *}$ respectively denote significance at the 5 percent and 10 percent levels. 
Table 5: (Continued)

Dependent Variable: Annual Probabillity of War, 1450 through 1700

\begin{tabular}{|c|c|c|c|c|c|c|}
\hline & \multicolumn{3}{|c|}{ Probit } & \multicolumn{3}{|c|}{ Robust Errors Probit } \\
\hline & (1) & $(2)$ & $(3)$ & (4) & (5) & (6) \\
\hline$O T T O M A N_{t-1}$ & $\ldots$ & $\cdots$ & $\begin{array}{l}-.111 \\
(.493)\end{array}$ & $\cdots$ & $\cdots$ & $\begin{array}{l}-.111 \\
(.321)\end{array}$ \\
\hline OTHEROTTOM AN $N_{t-1}$ & ... & $\cdots$ & $\begin{array}{l}-1.89 \\
(1.18)\end{array}$ & $\cdots$ & $\cdots$ & $\begin{array}{r}-1.89^{*} \\
(.571)\end{array}$ \\
\hline$E U R O P E_{t-1}$ & $\cdots$ & $\cdots$ & $\begin{array}{l}.881^{* *} \\
(.491)\end{array}$ & $\cdots$ & $\cdots$ & $\begin{array}{l}.881^{*} \\
(.260)\end{array}$ \\
\hline PROTESTANT $T_{t-1}$ & & $\cdots$ & $\begin{array}{l}7.29^{* *} \\
(4.40)\end{array}$ & & $\cdots$ & $\begin{array}{l}7.29^{*} \\
(1.05)\end{array}$ \\
\hline No. of obs. & 70 & 70 & 69 & 70 & 70 & 69 \\
\hline Pseudo $R^{2}$ & .263 & .324 & 768 & .263 & .324 & .768 \\
\hline
\end{tabular}

Note: ${ }^{*},{ }^{* *}$ respectively denote significance at the 5 percent and 10 percent levels. 